\title{
Fe and $\mathrm{Zn}$ effects on the Si cycle and diatom community structure in two contrasting high and low-silicate HNLC areas
}

\author{
K. Leblanc ${ }^{\mathrm{a}, *}$, C.E. Hare ${ }^{\mathrm{a}}$, P.W. Boyd ${ }^{\mathrm{b}}$, K.W. Bruland ${ }^{\mathrm{c}}$, B. Sohst ${ }^{\mathrm{c}}$, S. Pickmere ${ }^{\mathrm{b}}$, \\ M.C. Lohan ${ }^{\mathrm{c}}$, K. Buck ${ }^{\mathrm{c}}$, M. Ellwood ${ }^{\mathrm{b}}$, D.A. Hutchins ${ }^{\mathrm{a}}$ \\ ${ }^{a}$ College of Marine Studies, University of Delaware, 700 Pilottown Road, Lewes, DE 19958, USA \\ ${ }^{\mathrm{b}}$ NIWA Centre for Chemical and Physical Oceanography, Department of Chemistry, University of Otago, Dunedin, New Zealand \\ ${ }^{\mathrm{c}}$ Institute of Marine Sciences, University of California Santa Cruz. Santa Cruz, CA 95060/95064, USA
}

Received 3 November 2004; received in revised form 16 May 2005; accepted 1 June 2005

Available online 9 August 2005

\begin{abstract}
We compared the importance of $\mathrm{Fe}, \mathrm{Zn}$ and $\mathrm{Si}$ availability for diatom growth and silicification through microcosm enrichment experiments in two contrasting HNLC systems of the Sub-Arctic and Sub-Antarctic Pacific. The Bering Sea was characterized by low $\mathrm{Fe}$ and $\mathrm{Zn}$ concentrations $(<0.2 \mathrm{nM})$ but relatively high silicic acid $(5.6-15.9 \mu \mathrm{M})$. The addition of $0.25 \mathrm{nM} \mathrm{Fe}$ induced a 2-7-fold increase in diatom cell abundance (Pseudo-nitzschia sp. and Cylindrotheca closterium), an increase in $\mathrm{Chl} a$, biogenic silica, and particulate organic carbon and nitrogen, and a $2-3$-fold decrease in the average cellular Si content. Zn had no impact on biomass parameters or diatom community structure in this region.

The Sub-Antarctic Zone (SAZ) was a low Si-HNLC system, with initial silicic acid levels of $0.45 \mu \mathrm{M}$ and $\mathrm{Fe}$ and $\mathrm{Zn}$ concentrations $<0.03 \mathrm{nM}$. Si was the proximate limiting factor controlling diatom growth, followed by a secondary role for $\mathrm{Fe}$ on non-siliceous phytoplankton. In this region, we also found evidence for $\mathrm{Zn}$-mediated changes in diatom community structure. The presence of $\mathrm{Zn}(+1 \mathrm{nM})$ shifted the community away from a large colonial pennate (Pseudonitzschia sp.) towards a smaller and less silicified solitary pennate (Cylindrotheca closterium), potentially prone to more rapid silica dissolution in the surface layer.

Despite the dominance by the same two diatom genera, these two high-latitude regimes exhibited different nutrient limitation scenarios. Diatom growth in the Bering Sea was strongly Fe-limited, while the SAZ was mainly limited by $\mathrm{Si}$ and only secondarily by $\mathrm{Fe}$.
\end{abstract}

(C) 2005 Elsevier Ltd. All rights reserved.

Keywords: Iron; Zinc; Silicate; Diatoms; HNLC; HNLSiLC; Trace metal limitation

\footnotetext{
*Corresponding author.

E-mail address: leblanc@udel.edu (K. Leblanc).
} 


\section{Introduction}

Carbon export to the deep ocean by the biological pump is often associated with diatom blooms. The contribution of diatoms to total primary production ranges from $35 \%$ in open ocean waters to $75 \%$ in coastal upwelling areas (Nelson et al., 1995), and this group tends to dominate new production and export fluxes in turbulent, nutrient rich areas (Margalef, 1978; Legendre and Le Fèvre, 1989). Diatoms use dissolved $\mathrm{Si}$ to build their cell wall through biomineralization, but once formed, biogenic silica (BSi) is less readily recycled in the surface layer than the more labile organic carbon, nitrogen or phosphorus compounds, and is thus preferentially exported out of the euphotic layer (Dugdale et al., 1995; Buesseler, 1998). The surface ocean is therefore largely undersaturated with silicic acid, which consequently can often be limiting for diatom growth.

Phytoplankton productivity is not sustained at its full capacity in some areas despite high major nutrient levels, keeping vast open ocean regions biologically poor. The High Nutrient Low Chlorophyll (HNLC) areas are secluded from land masses and receive low atmospheric fluxes of iron-rich dust particles, leading to iron limitation of phytoplankton growth (Martin and Fitzwater, 1988; Martin et al., 1991). Fe-limitation has been conclusively demonstrated in these HNLC areas through mesoscale in situ enrichment experiments and microcosm bottle experiments (Martin et al., 1994; Coale et al., 1996; Boyd et al., 2000; Bakker et al., 2001; Law et al., 2001; Gervais et al., 2002; Tsuda et al., 2003; Coale et al., 2004; Boyd, 2004). Fe limitation also controls community structure in these regions, preventing the growth of larger species with high half-saturation constants for $\mathrm{Fe}$ uptake (Gall et al., 2001; Sedwick et al., 2000; Timmermans et al., 2001).

$\mathrm{Fe}$ availability has far-reaching implications for the biogeochemical cycles of C, N, P, and Si. For instance, $\mathrm{Fe}$ can induce significant alterations of diatom Si:N and $\mathrm{Si}: \mathrm{C}$ stoichiometric ratios (Hutchins and Bruland, 1998; Takeda, 1998; De La Rocha et al., 2000; Firme et al., 2003; Brzezinski et al., 2003; Leynaert et al., 2004;
Timmermans et al., 2004). As Fe is required for photosynthetic carbon acquisition and the synthesis of nitrate reductase, Fe-starved diatoms exhibit dramatically reduced carbon fixation and nitrate uptake rates (Geider and La Roche, 1994) while continuing to take up Si at slightly lowered rates (De La Rocha et al., 2000). Depending on the degree of Fe limitation, increases in the dissolved Si:N drawdown ratio by a factor of 1.4-3 have been observed (Takeda, 1998; Hutchins and Bruland, 1998; De La Rocha et al., 2000; Leynaert et al., 2004).

While Fe has received a great deal of attention, there has also been interest in the possible role of $\mathrm{Zn}$ in phytoplankton productivity (Morel et al., 1994). Zinc is a required nutrient for growth and is a cofactor for approximately 300 enzymes involved in nearly all aspects of cell metabolism (Anderson et al., 1978; Vallee and Auld, 1990). These include critical enzymes like carbonic anhydrase (Morel et al., 1994), which catalyzes inorganic carbon acquisition by supplying $\mathrm{CO}_{2}$ to RUBISCO, and alkaline phosphatase, which enables cells to acquire phosphorus from organic compounds under low P-conditions (Aksnes et al., 1994).

The potential role of $\mathrm{Zn}$ in controlling phytoplankton productivity and community structure is however less well documented. It typically occurs in concentrations $<0.1 \mathrm{nM}$ in surface waters (Bruland and Franks, 1983) and several studies have suggested that free $\mathrm{Zn}^{2+}$ concentrations could be limiting in the oceans, as $98 \%$ of the total dissolved $\mathrm{Zn}$ is chelated by strong ligands (Bruland, 1980, 1989; Ellwood and van den Berg, 2000; Lohan et al., 2002). Laboratory experiments suggest that low free $\mathrm{Zn}^{2+}$ concentrations can limit the growth of coastal species (Anderson et al., 1978; Brand et al., 1983) leading to the formulation of the "Zn-hypothesis" by Morel et al. (1994). However, relatively few experiments have been conducted with natural assemblages, and in most cases have shown very minimal effects of $\mathrm{Zn}$, if any, on the bulk phytoplankton community (Coale, 1991; Gall et al., 2001; Cochlan et al., 2002; Crawford et al., 2003; Coale et al., 2003).

Despite this, $\mathrm{Zn}$ availability could be low enough to control the growth of particular taxa 
and thus result in changes in species composition, for instance by shifting community structure away from diatoms and towards coccolithophorids (Sunda and Huntsman, 1995; Timmermans et al., 2001; Crawford et al., 2003). Several studies also demonstrated decreased $\mathrm{Si}$ uptake under $\mathrm{Zn}$ deficiency (Rueter and Morel, 1981; De La Rocha et al., 2000; Franck et al., 2003), suggesting that it may play a role in silicic acid transport or that it may have a structural role in frustule formation in diatoms. A recent study conducted by Ellwood and Hunter (2000) demonstrated that only a small percentage (1-3\%) of $\mathrm{Zn}$ taken up by diatoms was incorporated into diatom frustules, yet $\mathrm{Zn}$ could be involved in Si uptake without being incorporated into the frustule. Thus, the role of $\mathrm{Zn}$ on phytoplankton growth and diatom silicification remains unclear.

Our study was aimed at establishing the influence of $\mathrm{Fe}$ and $\mathrm{Zn}$ deficiency on diatom community structure and $\mathrm{Si}$ dynamics in two contrasting high-latitude, iron-limited regions of the Pacific Ocean. The HNLC surface waters of the Sub-Arctic Pacific (Bering Sea) exhibit a strong $\mathrm{W}$-E gradient in atmospheric dust deposition (Jickells and Spokes, 2001), and are enriched with nitrate, phosphate and silicic acid but depleted in Fe. In contrast, the Sub-Antarctic Zone (SAZ) S-E of New Zealand experiences $\mathrm{Fe}$ as well as $\mathrm{Si}$ limitation (Sedwick et al., 1997; Hutchins et al., 2001), and can be considered as an HNLSiLC (High Nitrate Low Silicate Low Chlorophyll) regime. The extent to which Fe-deficiency is responsible for the occurrence of these HNLSiLC regions is still unclear. Fe limitation may drive the preferential export of silica through a positive feedback on the "Si pump" (Dugdale et al., 1995) by either increasing diatom silicification rates relative to nitrate uptake (Hutchins and Bruland, 1998), or by increasing the reliance on regenerated nitrogen sources through inhibition of nitrate uptake (Brzezinski et al., 2003). Either mechanism would result in a faster selective depletion of silicic acid relative to nitrogen, thus leading to a system that is co-limited by both $\mathrm{Fe}$ and Si. Here we present a comparative study of the roles of $\mathrm{Fe}$ and $\mathrm{Zn}$ in these contrasting low and high silicate HNLC regimes, in which the effects of trace metal and $\mathrm{Si}$ availability on biogeochemical dynamics and diatom species composition were examined using combined $\mathrm{Si} / \mathrm{Fe} / \mathrm{Zn}$ additions to natural phytoplankton communities.

\section{Methods}

\subsection{Study sites}

Shipboard enrichment experiments were conducted in 2003 in two high-latitude HNLC systems. The first experiment was carried out in the SAZ during the FeCycle cruise south east of New Zealand (28 January-13 February) on board the R/V Tangaroa. Two other experiments were carried out on board R/V Kilo Moana (4 August-11 September) in the Bering Sea HNLC region (Fig. 1).

\subsection{Trace metal clean procedures and experimental setup}

During both cruises, whole seawater samples were collected $5 \mathrm{~m}$ below the surface using a trace metal clean Teflon diaphragm pump system. Seawater was sampled under a laminar flow hood in trace metal clean conditions. All incubation bottles were soaked in $10 \% \mathrm{HCl}$ for at least 3 weeks then rinsed with clean seawater from the pump 6 times prior to sampling. Whole seawater was collected in $4 \mathrm{~L}$ polycarbonate bottles during a period not exceeding $2 \mathrm{~h}$. Bottles were spiked randomly (Sub-Antarctic) or water was first homogenized in a $30 \mathrm{~L}$ carboy (Bering Sea) prior to sampling. Triplicate initial samples (T0) were analyzed for biomass and nutrient parameters as well as species composition.

In the Sub-Antarctic Zone experiment, 12 bottles (6 treatments in duplicate) were amended with $\mathrm{Fe}, \mathrm{Zn}$ and $\mathrm{Si}$ in different combinations. Treatments included unamended controls, $0.5 \mathrm{nM}$ added $\mathrm{Fe}(+\mathrm{Fe}), 4 \mu \mathrm{M}$ added $\mathrm{Si}(+\mathrm{Si}), 0.5 \mathrm{nM}$ added $\mathrm{Fe}$ and $4 \mu \mathrm{M}$ added $\mathrm{Si}(+\mathrm{FeSi}), 1 \mathrm{nM}$ added $\mathrm{Zn}$ and $4 \mu \mathrm{M}$ added $\mathrm{Si}(+\mathrm{ZnSi})$ and combined addition of $0.5 \mathrm{nM} \mathrm{Fe}, 1 \mathrm{nM} \mathrm{Zn}, 4 \mu \mathrm{M} \mathrm{Si}$ ( $+\mathrm{FeZnSi}$ ). The bottles were incubated for 7 days, with a final sampling and a mid-experiment 

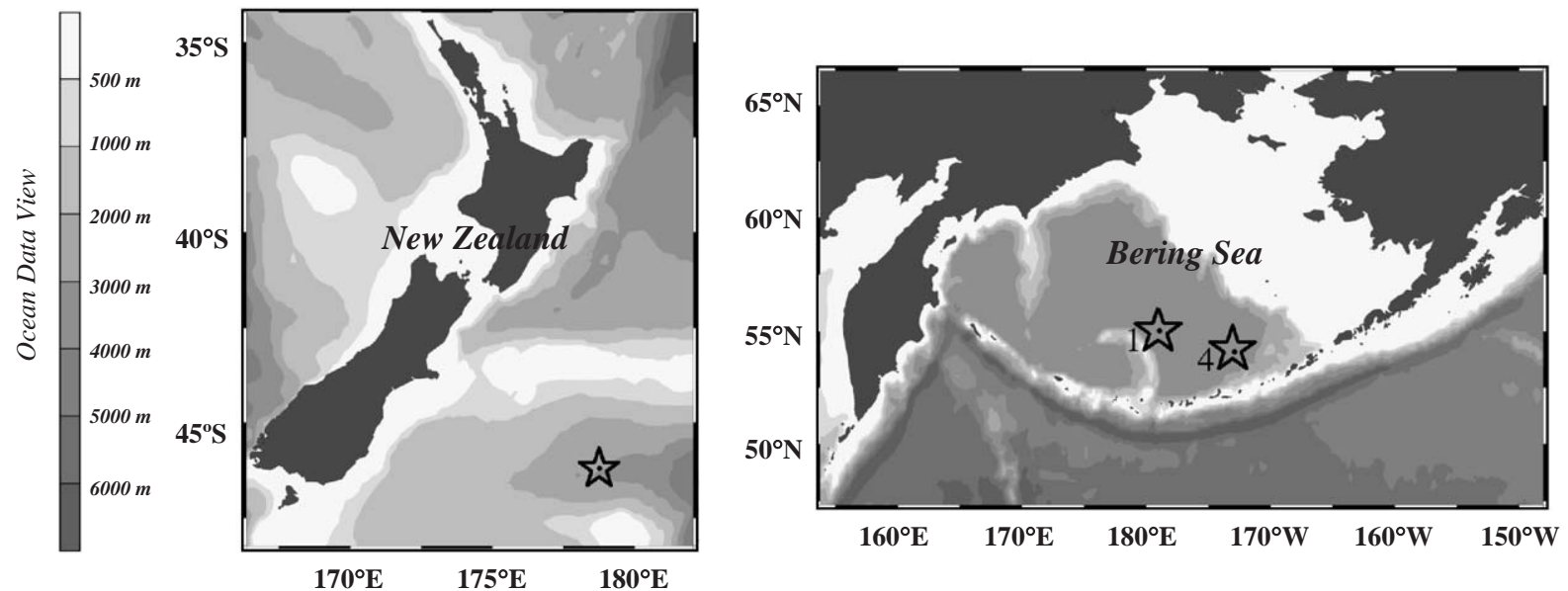

Fig. 1. Location of the sampling sites in the Sub-antarctic Zone (SAZ) near New Zealand and in the Bering Sea in the Sub-arctic Pacific.

sampling on day 3. Additions of $\mathrm{Si}(\mathrm{OH})_{4}$ were made from a trace metal clean chelexed $\mathrm{Na}_{2} \mathrm{SiO}_{3}$ solution. In the Bering Sea, triplicate bottles received amendments of $\mathrm{Fe}(+0.25 \mathrm{nM}), \mathrm{Zn}$ $(+0.50 \mathrm{nM})$, or combined $\mathrm{Fe} / \mathrm{Zn}$ and were incubated for 5-6 days with final and mid-point (day 3) samplings. The surface temperatures at all study sites were relatively low $\left(10-13{ }^{\circ} \mathrm{C}\right)$, leading to relatively low phytoplankton growth rates and therefore allowing each experiment to be carried out over 5-7 days without the community reaching senescence. Bottles were sealed with parafilm and tape and were maintained at in situ temperature in flow-through Plexiglass incubators. Blue Plexiglass screens limited incoming light levels to $50 \%$ of surface irradiance (Hutchins et al., 1998).

\subsection{Nutrients and trace metals}

Samples for dissolved nitrogen (nitrate + nitrite), phosphate and silicic acid were measured on board after filtration through $0.2 \mu \mathrm{m}$ Millex filters and analyzed on a Lachat QuickChem 8000 analyzer in the Bering Sea and on an Astoria Pacific Segmented Flow Analyzer in the SAZ cruise as described in Strickland and Parsons (1972). For the SAZ data, an average of each duplicate treatment is given, except for silicic acid on the final day of the experiment, where single points are plotted due to contamination of one set of the duplicate series after sampling.

Initial trace metals were measured on board at the beginning of each experiment. In the Bering Sea total dissolved $\mathrm{Zn}$ was determined by cathodic stripping voltammetry (Lohan et al., 2002; Ellwood and van den Berg, 2000). In the SAZ, total dissolved $\mathrm{Zn}$ was measured using the solvent extraction method according to Bruland et al. (1979). Total dissolved Fe $(<0.45 \mu \mathrm{m})$ was determined at sea using adsorptive cathodic stripping voltammetry (ACSV) on acidified and microwaved samples (Rue and Bruland, 1995 as modified by Bruland et al., 2005).

\subsection{Chlorophyll and particulates}

Chlorophyll $a$ samples were filtered onto 0.2 and $20 \mu \mathrm{m}$ polycarbonate membranes $(47 \mathrm{~mm}$, Whatman ${ }^{\circledR}$ ), extracted for $24 \mathrm{~h}$ in $90 \%$ acetone at $-20{ }^{\circ} \mathrm{C}$, and analyzed on board using a Turner Designs 10AU fluorometer (Parsons et al., 1984). Samples for particulate BSi were filtered onto $0.6 \mu \mathrm{m}$ polycarbonate membranes $\left(47 \mathrm{~mm}\right.$, Whatman $\left.{ }^{\mathbb{R}}\right)$, and dried on board for $24 \mathrm{~h}$ at $60{ }^{\circ} \mathrm{C}$. Samples were analyzed in the laboratory following the digestion of silica in hot $\mathrm{NaOH}$ for $45 \mathrm{~min}$ according to Nelson et al. (1989). Total particulate carbon and particulate organic nitrogen (PON) samples were collected by filtration 
onto $0.2 \mu \mathrm{m} \mathrm{GF} / \mathrm{F}$ filters $\left(25 \mathrm{~mm}\right.$, Whatman $\left.{ }^{\circledR}\right)$. Filters were dried at $60^{\circ} \mathrm{C}$ on board and analyzed at the laboratory using a Carlo-Erba $\mathrm{CHN}$ analyzer (Sharp, 1991). Samples were not fumed with $\mathrm{HCl}$ prior to analysis and theoretically contain both organic carbon and calcium carbonate. However, phytoplankton analysis revealed that coccolithophores were virtually absent from all samples at the time of sampling, thus the total particulate carbon data was treated as particulate organic carbon (POC).

\subsection{Cell counts}

Phytoplankton samples $(50 \mathrm{~mL})$ were preserved in $2 \%$ glutaraldehyde and stored at $4{ }^{\circ} \mathrm{C}$ in the dark until analysis. The samples were concentrated after gentle filtration under low vacuum pressure onto $0.2 \mu \mathrm{m}$ polycarbonate membranes $(25 \mathrm{~mm}$, Whatman ${ }^{\mathbb{R}}$ ) and resuspended in $1-2 \mathrm{~mL}$ of the filtered seawater. Diatoms were enumerated and identified on a direct light epifluorescence Olympus microscope in a hematocytometer, containing four chambers holding $25 \mu \mathrm{L}$. For each samples, 12 chamber units were counted. Diatoms were largely dominant in all treatments, with only very low numbers of other algal groups. Given that diatom community structure and Si biogeochemistry are the main focus of this study, only diatom cell counts are presented.

\section{Results}

\subsection{Initial conditions}

The coordinates, dates of sampling and initial ambient nutrients, trace metals, Chl $a$ and $\mathrm{BSi}$ concentrations for all study sites are summarized in Table 1. The surface layer was highly stratified in August in the Bering Sea, with a shallow mixed layer depth and temperature declining rapidly by 5-7 ${ }^{\circ} \mathrm{C}$ between the surface layer and $50 \mathrm{~m}$. The two HNLC sampling sites were characterized by high nutrient levels but low trace metal concentrations. Silicic acid concentrations were lower than nitrate concentrations at site 1 , with a dissolved molar Si:N ratio of 0.39 , but both nutrients were found at equal high levels $(>15 \mu \mathrm{M})$ at site 4 , with a dissolved molar $\mathrm{Si}: \mathrm{N}$ ratio of 1 .

Table 1

Sampling sites coordinates and initial nutrient and biomass status, SST (sea surface temperature), and MLD (mixed layer depth) in the two study regimes

\begin{tabular}{|c|c|c|c|}
\hline & \multicolumn{2}{|l|}{ Bering Sea HNLC } & \multirow[t]{2}{*}{ New Zealand HNLSiLC } \\
\hline & Site 1 & Site 4 & \\
\hline Latitude & $55.0^{\circ} \mathrm{N}$ & $54^{\circ} 0 \mathrm{~N}$ & $46.1^{\circ} \mathrm{S}$ \\
\hline Longitude & $178.5^{\circ} \mathrm{E}$ & $172.5^{\circ} \mathrm{E}$ & $178.5^{\circ} \mathrm{W}$ \\
\hline Date & 11 Aug 2003 & 30 Aug 2003 & 4 Feb 2003 \\
\hline SST & $10.7^{\circ} \mathrm{C}$ & $10.7^{\circ} \mathrm{C}$ & $13.5^{\circ} \mathrm{C}$ \\
\hline MLD & $20 \mathrm{~m}$ & $35 \mathrm{~m}$ & $40 \mathrm{~m}$ \\
\hline $\mathrm{Si}(\mathrm{OH})_{4}$ & $5.58 \pm 0.17 \mu \mathrm{M}$ & $15.90 \pm 0.10 \mu \mathrm{M}$ & $0.45 \pm 0.02 \mu \mathrm{M}$ \\
\hline $\mathrm{NO}_{3}+\mathrm{NO}_{2}$ & $14.22 \pm 0.29 \mu \mathrm{M}$ & $15.74 \pm 0.05 \mu \mathrm{M}$ & $6.62 \pm 0.04 \mu \mathrm{M}$ \\
\hline $\mathrm{PO}_{4}$ & $0.94 \pm 0.01 \mu \mathrm{M}$ & $0.85 \pm 0.04 \mu \mathrm{M}$ & $0.67 \pm 0.01 \mu \mathrm{M}$ \\
\hline $\mathrm{Fe}$ & $0.10 \overline{\mathrm{nM}}$ & $0.04 \mathrm{nM}$ & $0.03 \mathrm{nM}$ \\
\hline $\mathrm{Zn}$ & $0.06 \mathrm{nM}$ & $0.20 \mathrm{nM}$ & $0.006 \mathrm{nM}$ \\
\hline Chl $a$ Total & $0.50 \pm 0.03 \mu \mathrm{g} \mathrm{L}^{-1}$ & $0.77 \pm 0.22 \mu \mathrm{g} \mathrm{L}^{-1}$ & $0.51 \pm 0.01 \mu \mathrm{g} \mathrm{L}^{-1}$ \\
\hline $0.2-20 \mu \mathrm{m}$ & $77 \%$ & $89 \%$ & $83 \%$ \\
\hline$>20 \mu \mathrm{m}$ & $23 \%$ & $11 \%$ & $17 \%$ \\
\hline BSi Total & $1.08 \pm 0.01 \mu \mathrm{mol} \mathrm{L}^{-1}$ & $0.58 \pm 0.03 \mu \mathrm{mol} \mathrm{L}^{-1}$ & $0.10 \pm 0.02 \mu \mathrm{mol} \mathrm{L}^{-1}$ \\
\hline $0.2-20 \mu \mathrm{m}$ & $34 \%$ & $62 \%$ & no data \\
\hline$>20 \mu \mathrm{m}$ & $66 \%$ & $38 \%$ & no data \\
\hline
\end{tabular}


In the SAZ, the sampling area was an HNLSiLC region as indicated by the submicromolar ambient $\mathrm{Si}(\mathrm{OH})_{4}$ concentrations and a molar Si:N ratio of 0.07 . In both regimes, dissolved $\mathrm{Fe}$ and $\mathrm{Zn}$ concentrations were extremely low $(<0.10 \mathrm{nM})$, except for a $\mathrm{Zn}$ concentration of $0.20 \mathrm{nM}$ at site 4 in the Bering Sea. The autotrophic community was dominated by small cells in both regions, with Chl $a$ primarily in the nano-and picoplanktonic $(0.2-20 \mu \mathrm{m})$ size fractions. Chl $a$ concentrations were nearly equivalent in the Bering Sea and in the SAZ, with only slightly higher concentrations $(25 \%)$ at Bering Sea site 4 , while $\mathrm{BSi}$ values were 6-10 times higher in the Bering Sea than in the SAZ. In the Bering Sea, the high BSi concentration at site 1 was mostly due to the presence of microplanktonic $(>20 \mu \mathrm{m})$ diatoms, while site 4 was initially dominated by nanoplanktonic diatoms.

\subsection{The Bering sea-a high silicate $H N L C$ area}

\subsubsection{Phytoplankton biomass}

At the first Bering Sea site (site 1), Fe additions alone or in combination with $\mathrm{Zn}$ had a major impact on biomass and significantly increased biomass parameters such as $\mathrm{Chl} a, \mathrm{BSi}, \mathrm{PON}$ and POC $(P<0.005)$ by the end of the experiment (Fig. $2 \mathrm{~A}-\mathrm{D})$. $\mathrm{Zn}$ addition alone had no impact on any of those parameters and biomass in this treatment was not significantly different from the controls throughout the incubation. Similarly, all parameters in the $+\mathrm{Fe}$ and $+\mathrm{FeZn}$ treatments were not statistically different from one another $(P>0.05, t$-test $)$. Significant increases in $\mathrm{Chl} a$ concentrations $(P<0.005)$ in both $\mathrm{Fe}$ additions were already observed by day 3 . The mean $\mathrm{Chl} a$ concentration increased by a factor of 6 between the control $/+\mathrm{Zn}$ and the $+\mathrm{Fe} /+\mathrm{FeZn}$ treatments by day 6 , reaching $4 \mu \mathrm{g} \mathrm{L}^{-1}$ in the latter treatments. In contrast, the Chl $a$ increase in the control and $+\mathrm{Zn}$ amendments was moderate between days 0 and $6(+36 \%)$ (Fig. 2A).

The siliceous biomass showed the same trends as $\mathrm{Chl} a$, but the relative increase in both $\mathrm{Fe}$ additions was slightly lower (Fig. 2B). By day 3, $\mathrm{BSi}$ concentrations were not yet differentiated between treatments. By day 6 , the final mean $\mathrm{BSi}$ concentration in both Fe additions $\left(5.15 \mu \mathrm{mol} \mathrm{L}^{-1}\right)$ was significantly higher $(P<0.005)$ by a factor of 2.4 than the average concentration in the control/ $+\mathrm{Zn}$ amendments $\left(2.12 \mu \mathrm{mol} \mathrm{L}^{-1}\right)$. The average BSi concentration in the control by day 3 was slightly higher than in all other treatments, but this difference was not statistically significant.

The POC and PON data were closely correlated and followed the same pattern in all amendments (Fig. 2C and D). Concentrations were significantly higher $(P<0.005)$ and increased by a factor of 3 in both $\mathrm{Fe}$ additions compared to the Fe-deplete bottles by day 6 . By the middle of the experiment, an increase in the average values of POC and PON was observed in all treatments relative to the control, even though this was not significant. This was paralleled by an increase in Chl $a$ in both Fe treatments while $\mathrm{BSi}$ concentrations remained lower than the control, suggesting the growth of non-siliceous phytoplankton by day 3 .

Growth observed in the control compared to T0 also suggests the alleviation of light limitation, trace Fe contamination, or alleviation of micrograzing pressure in the bottles, thus allowing for pico- or nanoplanktonic cells with fast growth rates to develop in the first part of the experiment. The addition of trace metals however clearly benefited diatoms, which then dominated by the end of the experiment in the $+\mathrm{Fe}$ treatments. A decrease in POC and PON values in the control and $\mathrm{Zn}$ treatments is noticeable at site 1 between days 3 and 6 (Fig. 2C and D) and suggests that part of the biomass is being removed by grazers. It is likely that grazers were present in all bottles, but that growth stimulation in both $\mathrm{Fe}$ amendments resulted in a net accumulation of biomass.

The BSi:POC and BSi:PON ratios of the controls and all trace metal additions $(\mathrm{Zn}, \mathrm{Fe}$ and $\mathrm{FeZn}$ ) were only significantly different on day 3 , which may have resulted from the growth of non-siliceous phytoplankton (Fig. 2E and F). The mean BSi:POC ratio was initially 0.093, and decreased significantly by day 3 , with an average value of 0.044 in all trace metal enrichments while the control decreased only slightly to 0.085 . By the last day of the experiment, $\mathrm{BSi}$ POC ratios increased again to values between 0.118 and 0.148 , with a ratio slightly lower in both $\mathrm{Fe}$ 
Bering Sea Site 1

(A)
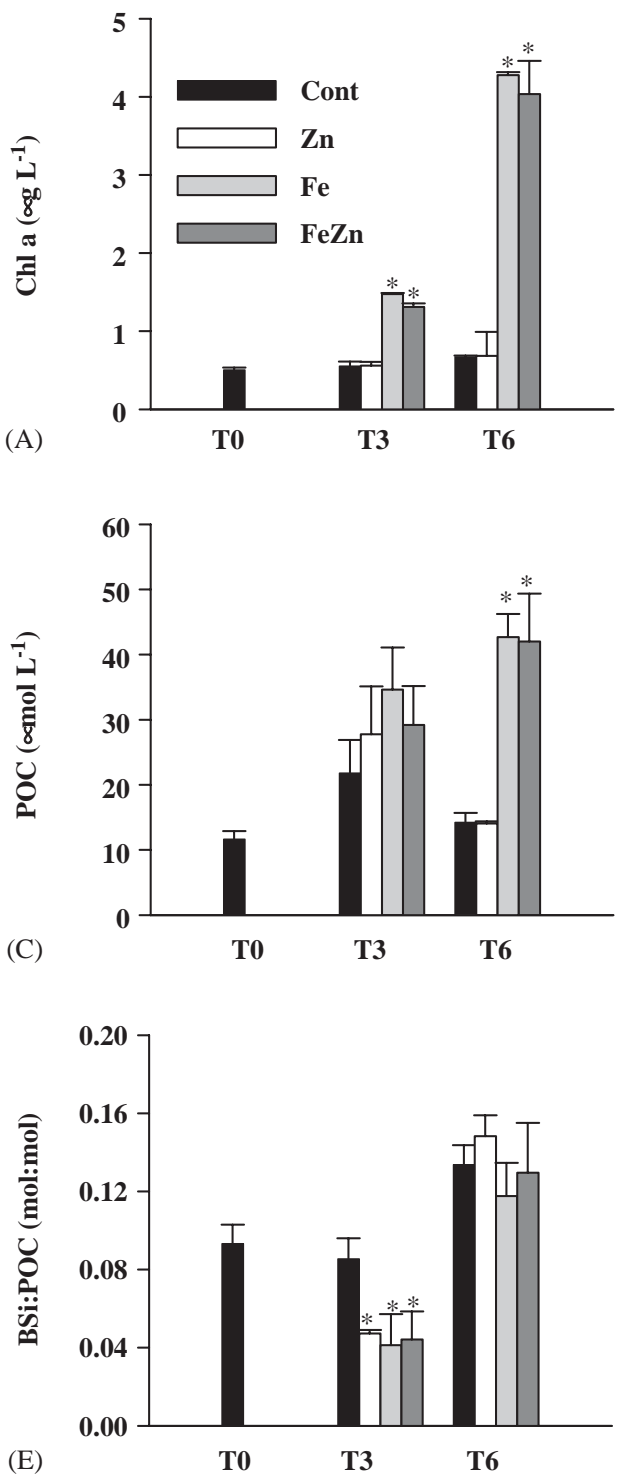
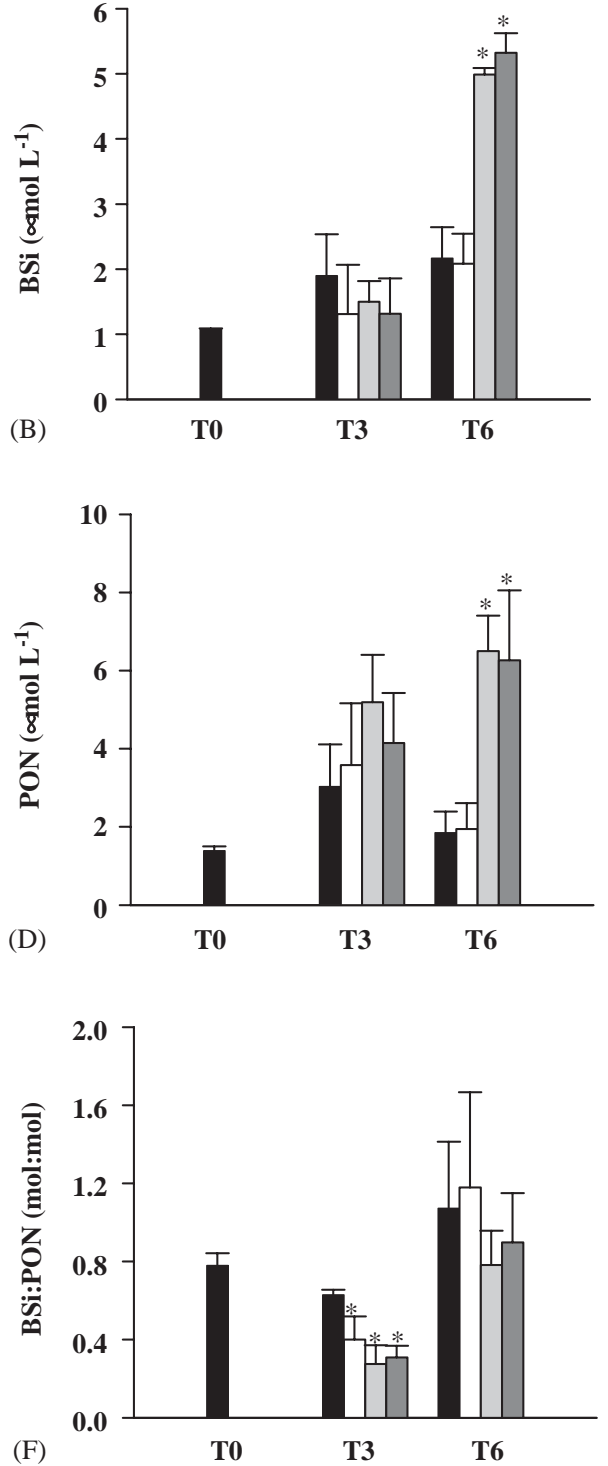

Fig. 2. Biomass parameters over a 6 day incubation period at site 1 in the Bering Sea. (A) Chl $a$ (Chlorophyll $a$ ) in $\mu \mathrm{g} \mathrm{L}{ }^{-1},(\mathrm{~B}) \mathrm{BSi}$ (Biogenic Silica) in $\mu \mathrm{mol} \mathrm{L}^{-1}$, (C) POC (Particulate Organic Carbon) in $\mu \mathrm{mol} \mathrm{L}^{-1}$, (D) PON (Particulate Organic Nitrogen) in $\mu \mathrm{mol} \mathrm{L}{ }^{-1}$, (E) BSi:POC molar ratios in mol:mol, and (F) BSi:PON molar ratios in mol:mol. Error bars represent the standard deviations of triplicate treatments $(n=3)$. Stars above histogram bars indicate a triplicate average that was significantly different from the control for the same sampling day $(P<0.05, t$-test, $\mathrm{df}=4)$.

additions. BSi:PON ratios followed the same pattern, with values as low as 0.27 on day 3 followed by increases to values between 0.78 and 1.07 by the end of the growout.
At site 4 , the same impacts of $\mathrm{Fe}$ additions were generally observed but with a slightly lower magnitude (Fig. 3A-F). Increases in Chl $a$ in both $+\mathrm{Fe} /+\mathrm{FeZn}$ treatments were already 
significantly higher than in the control treatment by day $3(P<0.005)$ and remained so by day 6 with a final average increase by a factor 2.5 compared to the control (Fig. 3A). Final values were lower than at site 1 , with a maximum of $2.40 \mu \mathrm{g} \mathrm{L}^{-1}$ in the $+\mathrm{FeZn}$ treatment. The average Chl $a$ concentration in the $+\mathrm{Zn}$ treatment was slightly lower than the control throughout the experiment, significantly so on day 3 $(P<0.05)$.

Bering Sea Site 4

(A)

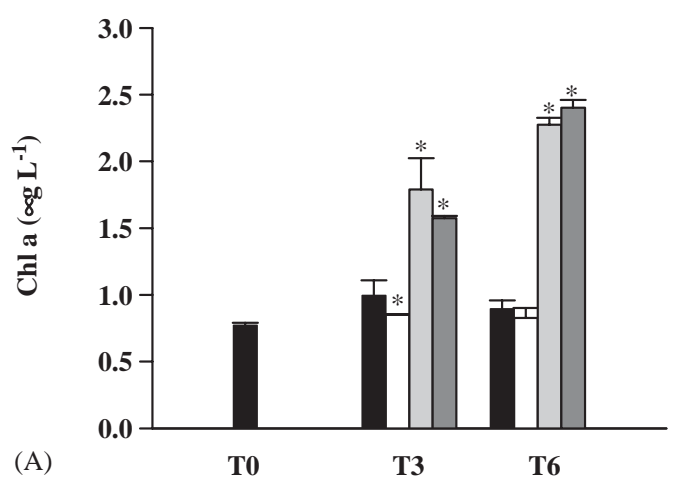

(C)
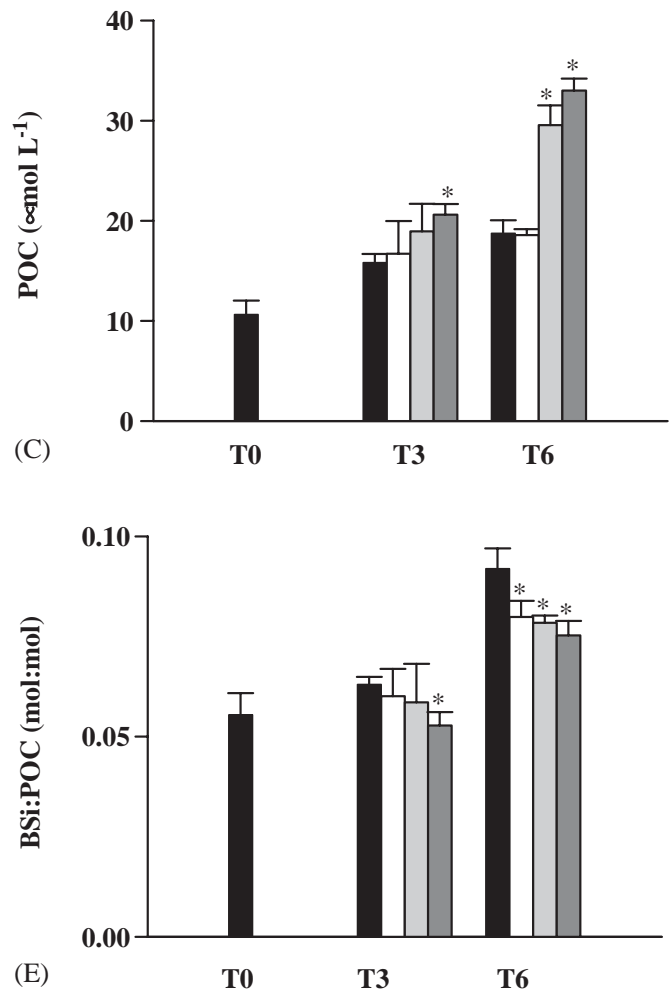
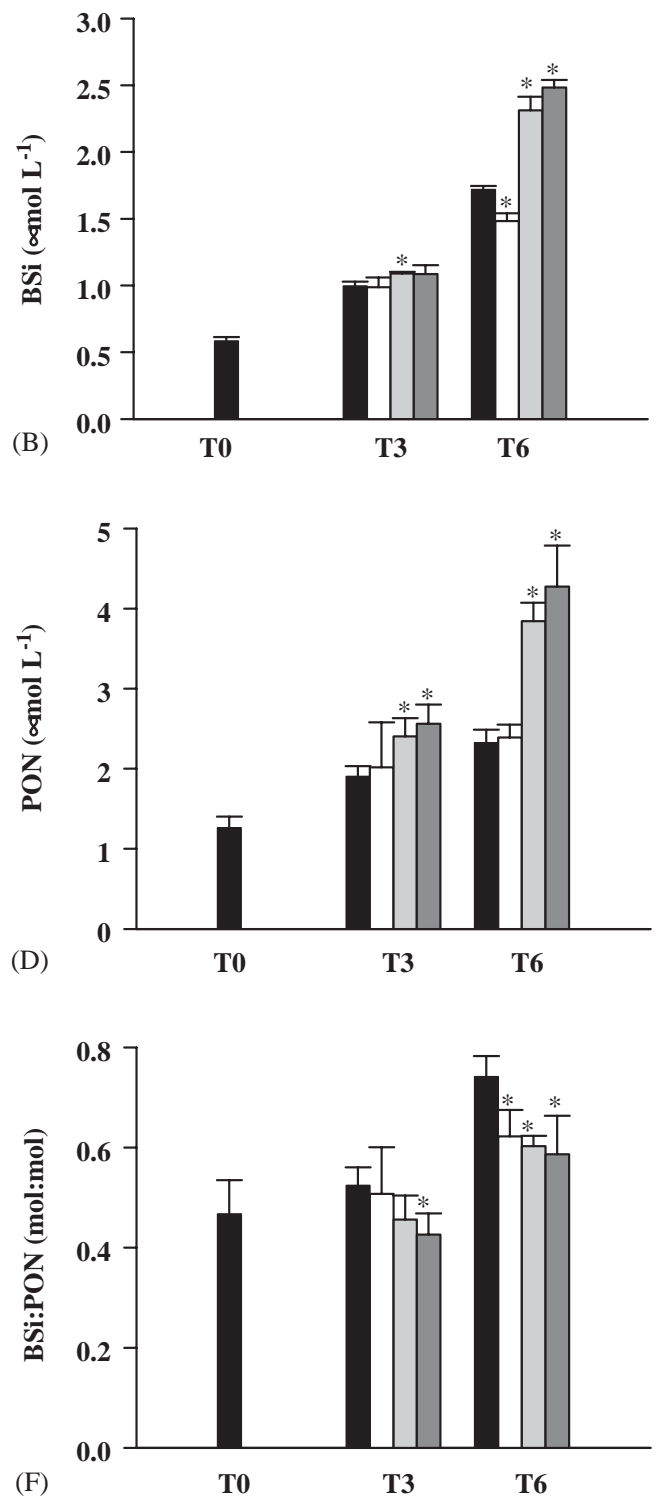

Fig. 3. Biomass parameters over a 5 days incubation period at site 4 in the Bering Sea. (A) Chl $a$ (Chlorophyll $a)$ in $\mu \mathrm{g} \mathrm{L}{ }^{-1},(\mathrm{~B}) \mathrm{BSi}$ (Biogenic Silica) in $\mu \mathrm{mol} \mathrm{L}^{-1}$, (C) POC (Particulate Organic Carbon) in $\mu \mathrm{mol} \mathrm{L}{ }^{-1}$, (D) PON (Particulate Organic Nitrogen) in $\mu \mathrm{mol} \mathrm{L}{ }^{-1}$, (E) BSi:POC molar ratios in mol:mol, and (F) BSi:PON molar ratios in mol:mol. Error bars, triplicate averages and symbols as in Fig. 2. 
Siliceous biomass increased more strongly in the controls by the end of the experiment compared to the initial content than $\operatorname{did} \mathrm{Chl} a$, which remained stable (Fig. 3A and B). However, like site 1 the increases in the $+\mathrm{Fe} /+\mathrm{FeZn}$ treatments were significantly higher than in the control $(P<0.0005)$, in this case by a factor of 1.4 . BSi concentrations were on the other hand significantly lower in the $+\mathrm{Zn}$ treatment $(P<0.005)$ than in the control by day 6 .

POC and PON concentrations followed the same pattern, with the largest increase by day 3 in the $+\mathrm{FeZn}$ treatment, while both $+\mathrm{Fe}$ and + FeZn treatments exhibited the highest concentrations by day 6 (Fig. 3C and D). Similarly to site 1 , a noticeable increase in POC, PON and Chl $a$ occurred in the trace metal enriched bottles by day 3 while BSi concentrations remained similar to the control, suggesting again the growth of nonsiliceous phytoplankton at the midpoint of the experiment. By day 6 , the average increase in the $+\mathrm{Fe} /+\mathrm{FeZn}$ treatments for both POC and PON was 1.7 compared to the control and $+\mathrm{Zn}$ bottles.

BSi:POC and BSi:PON ratios were lower at site 4 than at site 1 for all treatments, which can be explained by the lower initial siliceous biomass present (Fig. 3E and F). Both BSi:POC and BSi:PON ratios increased by $30 \%$ in the control between T0 and T6 (BSi:POC from 0.055 to 0.092 , BSi:PON from 0.47 to 0.74$)$. A slight decrease of both ratios was observed in the trace metal treatments compared to the control by days 3 and 6, with the lowest values observed in the $+\mathrm{FeZn}$ amendment $\quad$ BSi:POC $=0.075$, $\mathrm{BSi}: \mathrm{PON}=0.49$ ), likely resulting from the growth of non-siliceous phytoplankton.

\subsection{Diatom abundance and community structure}

Total diatom abundance at the end of the experiment was divided into centrics and pennates (Fig. 4). At site 1, pennates dominated the diatom community, and constituted $90-93 \%$ of all diatoms (Fig. 4A). The addition of Fe significantly $(P<0.005)$ increased the abundance of pennates by a factor of 7 by day 6 , with an average of 4600 cells $\mathrm{mL}^{-1}$ in both $\mathrm{Fe}$ additions. In the control and $+\mathrm{Zn}$ treatments, their abundance only averaged 600 cells $\mathrm{mL}^{-1}$. The total diatom abundance was slightly lower in the $\mathrm{Zn}$ amendment $\left(530\right.$ cells $\mathrm{mL}^{-1}$ ) compared to the control (865 cells $\mathrm{mL}^{-1}$ ).

At the end of the experiment, the phytoplankton community consisted mainly of two species: a large chain forming pennate Pseudo-nitzschia sp. (50-80 $\mu \mathrm{m}$ long and $5 \mu \mathrm{m}$ wide) and Cylindrotheca closterium, a much smaller pennate $(15-25 \mu \mathrm{m}$ and $2 \mu \mathrm{m}$ wide) present only as solitary cells (Figs. 4B and 5). These two species represented as much as $80-89 \%$ of all pennates, and their relative abundance was fairly similar in all treatments.

A very similar diatom community was found at site 4, where pennates were dominant again, constituting from $93 \%$ to $95 \%$ of the diatom assemblage (Fig. 4C). However, compared to site 1 , the only significant increase in total diatom abundance was observed in the $+\mathrm{Fe}$ treatment $(P<0.005)$ with an average of 2300 cells $\mathrm{mL}^{-1}$ compared to less than 1000 cells $\mathrm{mL}^{-1}$ in the control. Diatom abundance increased by a factor 1.8 in two out of the three $+\mathrm{FeZn}$ treatments compared to the control by day 6 . Low diatom abundance in the last replicate, however, decreased the average abundance for this treatment to 1300 diatoms $\mathrm{mL}^{-1}$. The diatom community at the end of the experiment was dominated by the same two species found at site 1 (Cylindrotheca closterium and Pseudo-nitzschia sp.). These two diatoms were also found in almost the same proportions, with a contribution of the small Cylindrotheca on average $10 \%$ higher at site 4 than at site 1 (Fig. 4D). For both experiments, diatom community structure remained very similar in all treatments by the end of the incubations (Fig. 4B and D).

In order to better visualize the difference in size of these two species, a photograph of these diatoms taken under epifluorescence microscopy is shown in Fig. 5. Diatoms were labeled with PDMPO, a new fluorescent marker that is selectively incorporated into new diatom frustules and fluoresces under UV-light (Shimizu et al., 2001; Leblanc and Hutchins in press - see note on figure legend). This picture reveals new $\mathrm{BSi}$ deposition after a $24 \mathrm{~h}$ incubation period, and 
Bering Sea Site 1
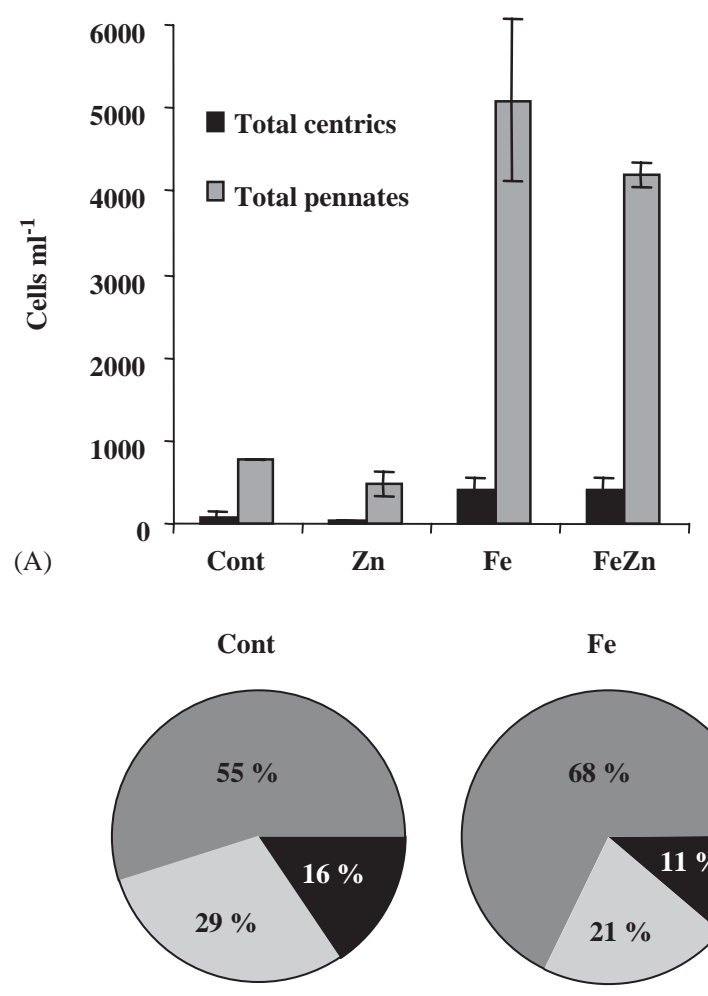

$\mathbf{Z n}$

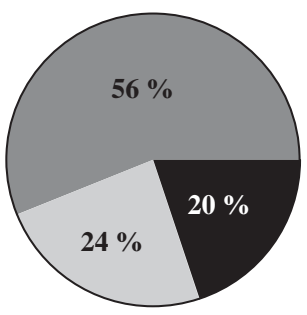

$\mathrm{Fe}$

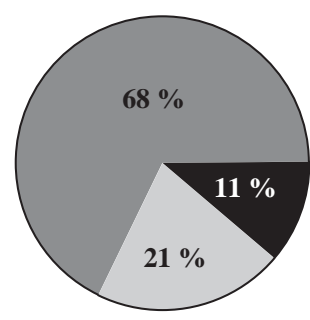

FeZn

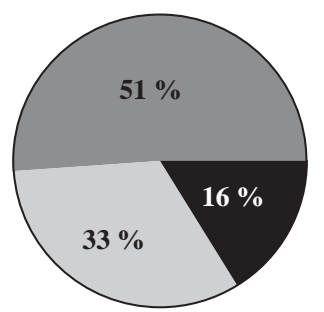

(B)
Bering Sea Site 4

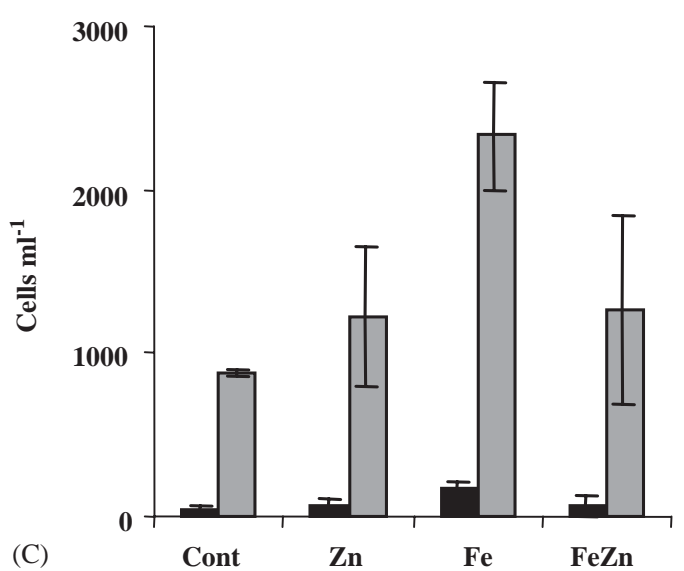

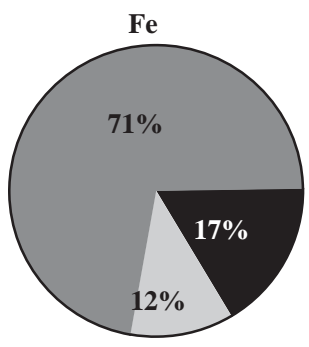

(D)

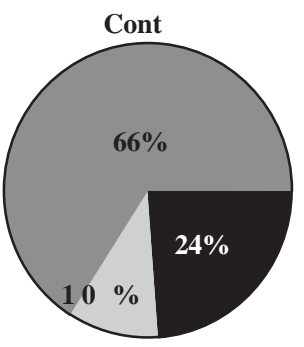

Zn
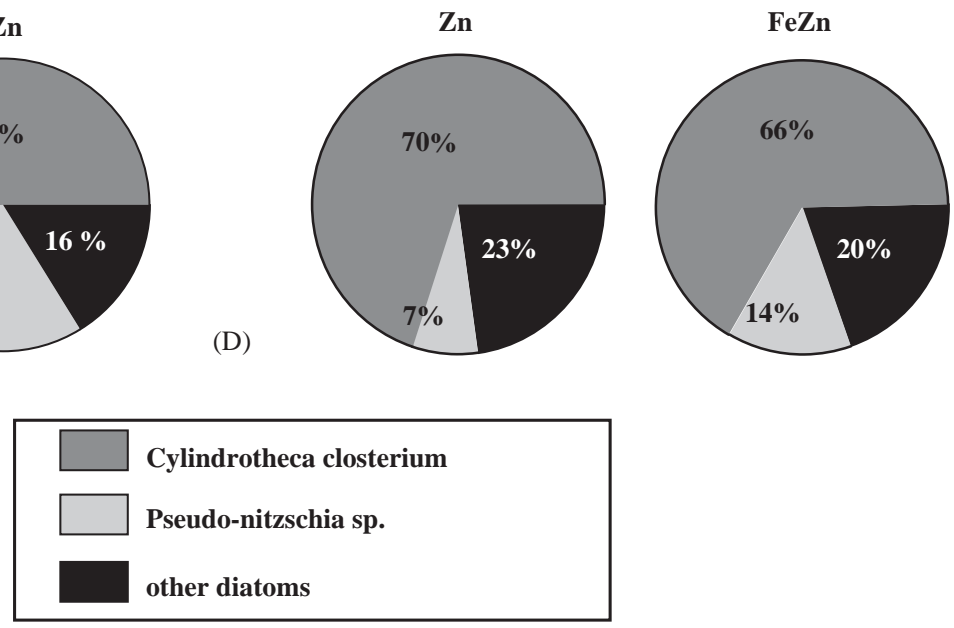

Fig. 4. Top panels: Diatom abundance for both centrics and pennates on the final day of the enrichment experiments conducted at site 1 (panel A) and at site 4 (panel C) in the Bering Sea. Standard deviations were derived from cell counts in triplicate bottles. Bottom panels: Relative abundance of the two dominant diatom species (Pseudo-nitzschia sp. and Cylindrotheca closterium) at site 1 (B) and at site 4 (D) on the final day of the experiment. 


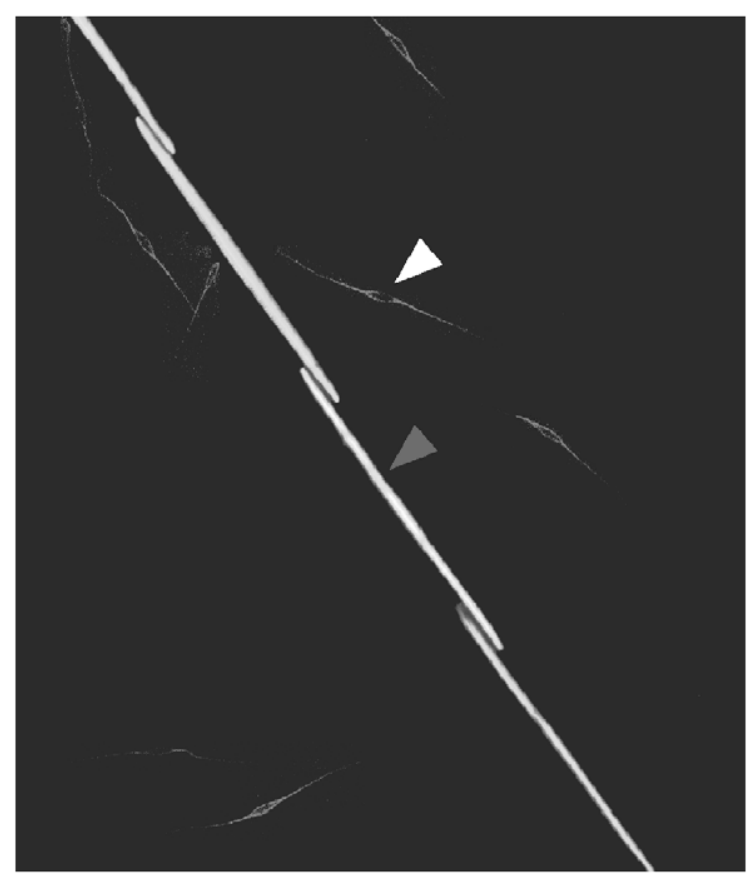

Fig. 5. Photograph of the two dominant pennate species in the Bering Sea enrichment experiments under fluorescence microscopy. Diatom cells were labeled with PDMPO, a silicification tracer which fluoresces wherever new biogenic silica is formed (see Shimizu et al., 2001, Leblanc and Hutchins, in press). The white surfaces on this photograph thus represent new frustule formation for both species. From this picture, obvious differences in size and frustule thickness are apparent between the colonial Pseudo-nitzschia sp. (grey arrow), and the unicellular Cylindrotheca closterium (white arrow).

demonstrates the differences in size and degree of silicification of both species.

\subsection{Nutrient drawdown}

$\mathrm{Si}(\mathrm{OH})_{4}$ and $\mathrm{NO}_{3}^{-}$depletion for both sites are shown in Fig. 6. At site 1, $\mathrm{NO}_{3}^{-}$decreased slowly by an average of $2 \mu \mathrm{M}$ ( $15 \%$ of the initial stock) over the course of the experiment in the control/ $+\mathrm{Zn}$ amendments (Fig. 6A). $\mathrm{NO}_{3}^{-}$utilization was significantly higher in both $\mathrm{Fe}$ additions $(P<0.0005)$, with an average decrease of $7.8 \mu \mathrm{M}$ from days 0 to 6 , representing $55 \%$ of the initial stock. In contrast, $\mathrm{Si}(\mathrm{OH})_{4}$ was almost entirely depleted in both Fe additions, with submicromolar concentrations left by day $6(0.3 \mu \mathrm{M}$ in the $+\mathrm{Fe}$ and $0.7 \mu \mathrm{M}$ in the $+\mathrm{FeZn}$ ), representing a respective uptake of $94 \%$ and $88 \%$ of the initial silicic acid stock (Fig. 6B). The decrease was much less in the control $/+\mathrm{Zn}$ treatments, with an uptake of $47 \%$ and $34 \%$ of the initial stock, respectively.

The Si:N utilization ratio differed between the Fe-replete and Fe-deplete samples (Fig. 6C). The final Si:N drawdown ratio (calculated as

$\left.\left(\left[\mathrm{Si}(\mathrm{OH})_{4}\right]_{\text {final }}-\left[\mathrm{Si}(\mathrm{OH})_{4}\right]_{\text {initial }}\right) /\left(\left[\mathrm{NO}_{3}{ }^{-}\right]_{\text {final }}-\left[\mathrm{NO}_{3}{ }^{-}\right]_{\text {initial }}\right)\right)$

averaged $1.1 \pm 0.12$ at site 1 in the control $/+\mathrm{Zn}$ treatments. This was significantly higher $(P<0.0005)$ than in both $\mathrm{Fe}$ treatments, for which the average drawdown ratio was $0.65 \pm 0.02$.

Nutrient drawdown at site 4 occurred in a different manner compared to site 1 . The $\mathrm{NO}_{3}^{-}$ drawdown was still significantly higher in both $+\mathrm{Fe} /+\mathrm{FeZn}$ treatments $(-19 \%)$ by the end of the experiment than in the control/ $+\mathrm{Zn}(-3 \%)$, but this consumption was less substantial than at site 1 where $\mathrm{NO}_{3}^{-}$was depleted to more than half of its initial value (Fig. 6D). Silicic acid drawdown was even less efficient with a mere $10 \%$ decrease from the start to the end of the experiment. Furthermore, there was no statistical difference between any of the treatments for silicic acid drawdown (Fig. 6E).

This differential drawdown resulted in significantly higher Si:N utilization ratios in both the control $/+\mathrm{Zn}$ treatments $(2.93 \pm 0.13$ and $2.15 \pm 0.60$, respectively) than in both + Fe treatments where the $\mathrm{Si}: \mathrm{N}$ ratio was as low as $0.59 \pm 0.31$ and $0.52 \pm 0.26$, respectively (Fig. 6F).

\subsection{Si cellular quotas}

Despite the dominance of diatoms at the end of the incubation, they are probably not the only organisms responsible for nitrogen drawdown. Thus we investigated the Si quota per diatom cell using both $\mathrm{BSi}$ measurements and silicic acid drawdown. Because species composition was very similar between treatments (Fig. 4B and D), we were able to make a direct comparison of cell silicification by normalizing two independent measurements, the produced $\mathrm{BSi}$ and the silicic 
Site 1
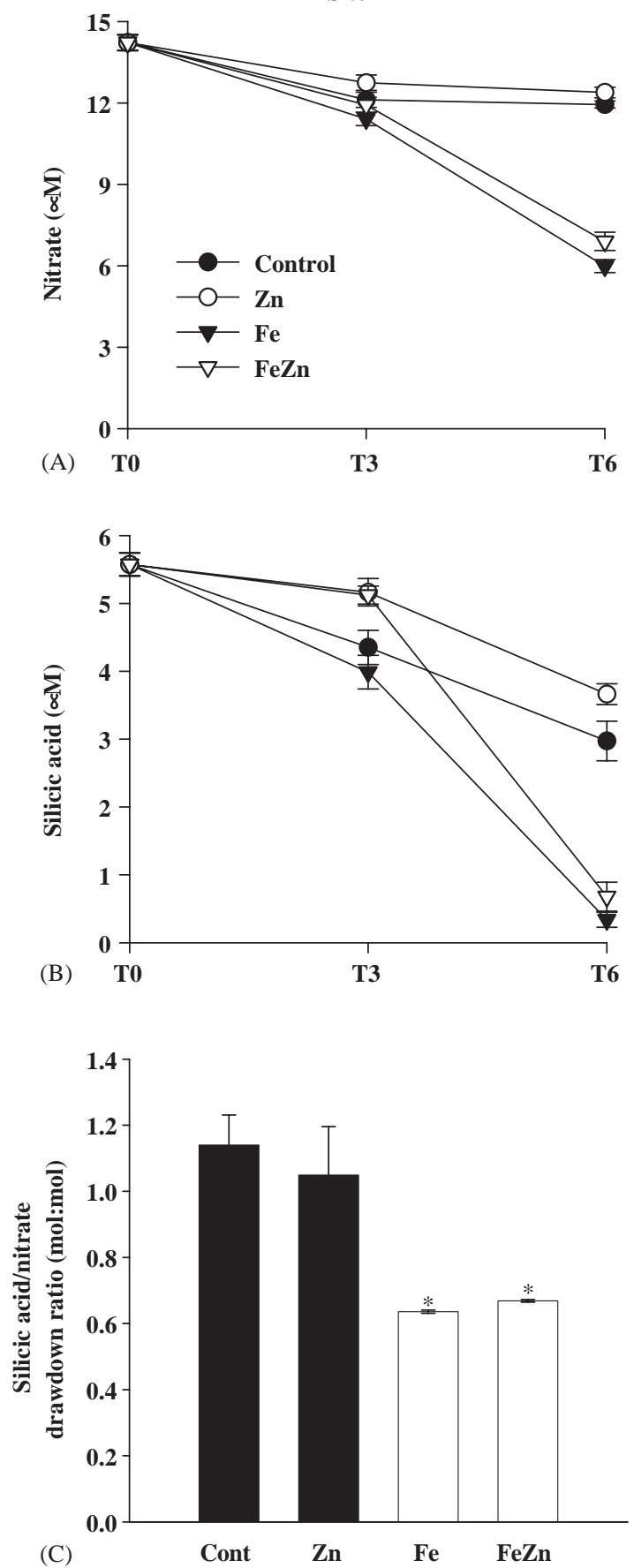

Site 4
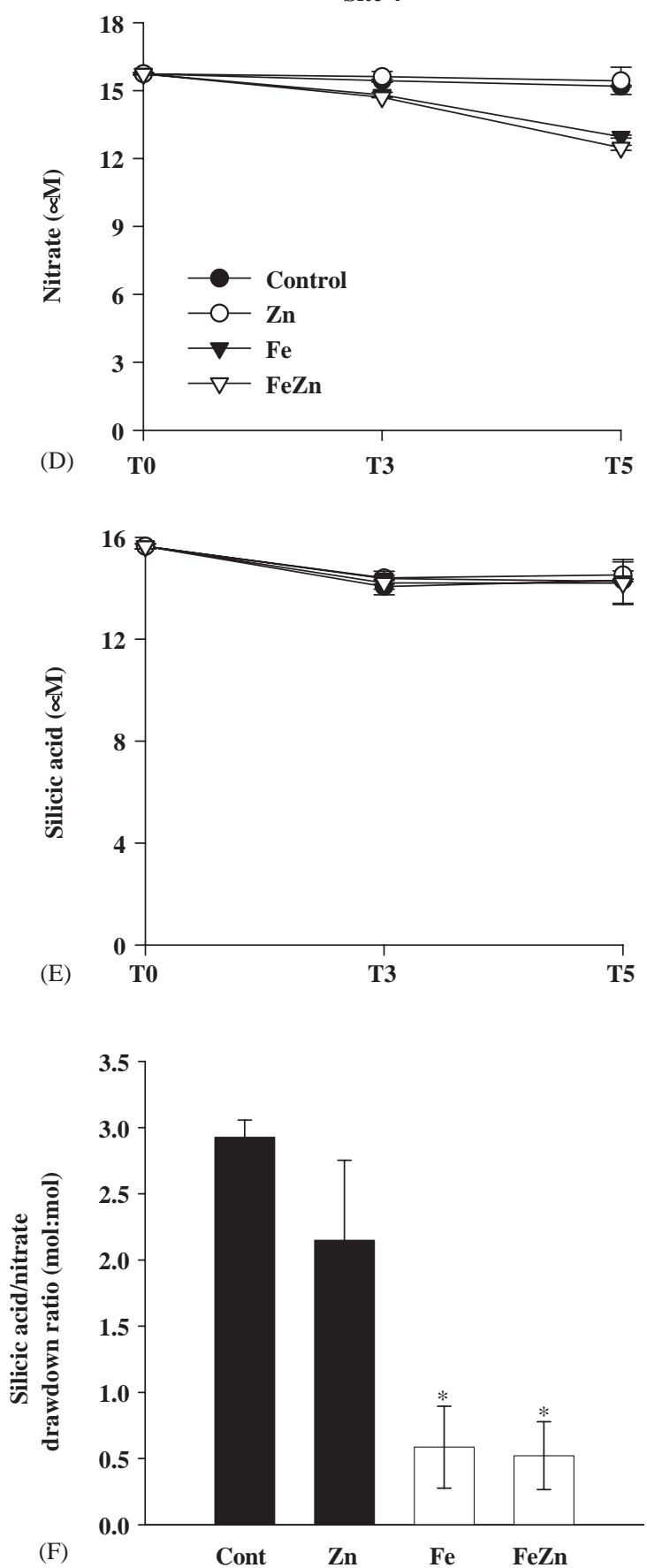

Fig. 6. (A and $\mathrm{B}) \mathrm{NO}_{3}^{-}$and $\mathrm{Si}(\mathrm{OH})_{4}$ utilization $(\mu \mathrm{M})$ in the Bering Sea at site 1 during the course of the experiment (6 days). (C) Si:N drawdown ratios calculated as described in Eq. (1). Error bars represent standard deviations of triplicate treatments $(n=3)$. (D and E) $\mathrm{NO}_{3}^{-}$and $\mathrm{Si}(\mathrm{OH})_{4}$ utilization $(\mu \mathrm{M})$ in the Bering Sea at site 4 during the course of the experiment (5 days). (F) Si:N drawdown ratios calculated as described in Eq. (1). 

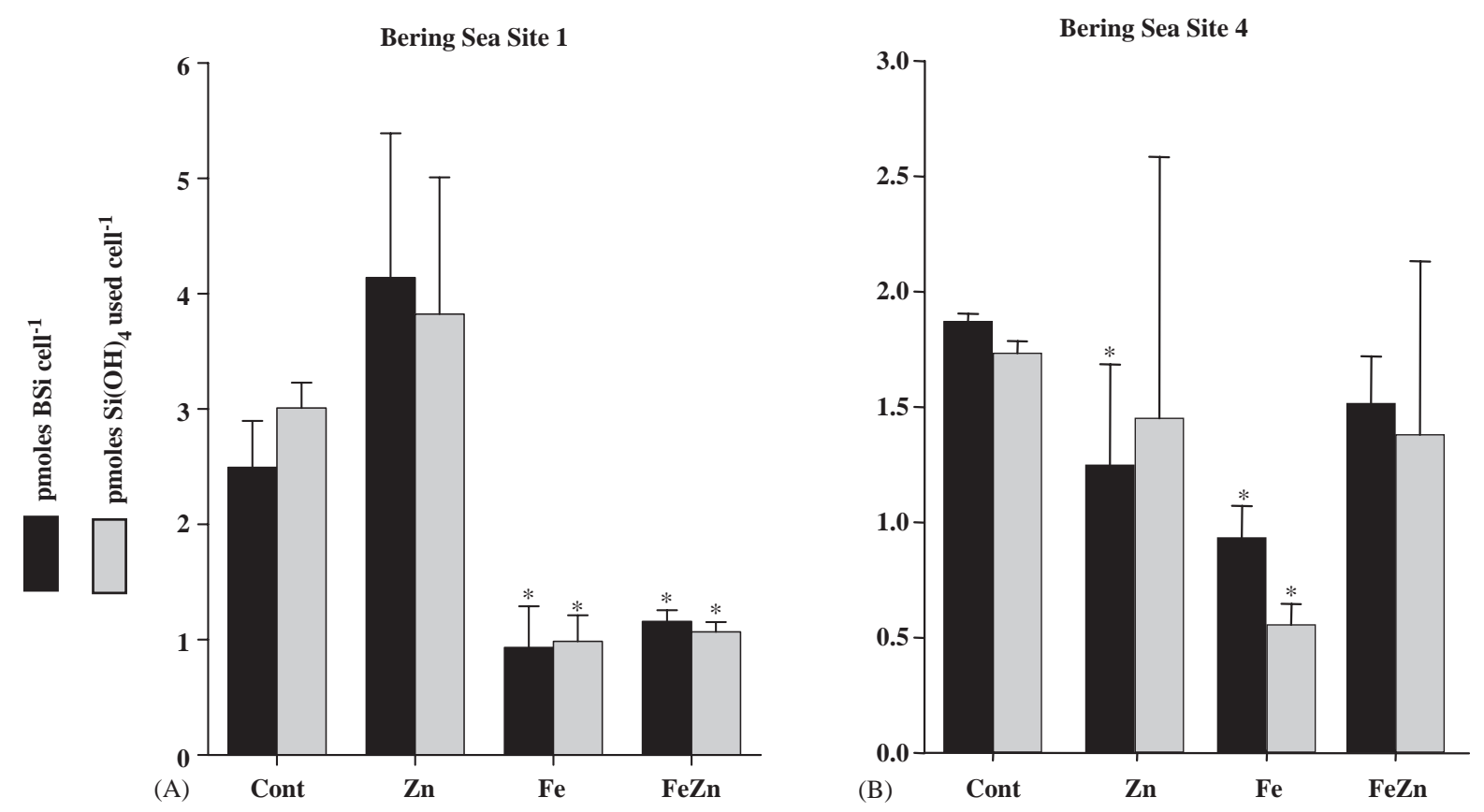

Fig. 7. Average cellular Si quotas (in pmol Si cell ${ }^{-1}$ ) derived for the total diatom community in the Bering Sea experiment at site 1 (A) and 4 (B). Si quotas were calculated from both biogenic silica produced (black bars) and from the quantity of $\mathrm{Si}(\mathrm{OH})_{4}$ used (gray bars), normalized to the total number of diatoms. Error bars represent standard deviation of triplicate treatments $(n=3)$.

acid used, to diatom abundance (Fig. 7A and B). The $\mathrm{Si}$ quota is calculated for a mixed diatom assemblage and is not representative of a true value for a particular species, but given the same mix of species present, it is possible to infer the impact of trace metals on an "average" diatom $\mathrm{Si}$ quota. At site 1, the average cellular $\mathrm{Si}$ quotas derived from $\mathrm{BSi}$ concentrations and $\mathrm{Si}(\mathrm{OH})_{4}$ drawdown were very conservative $\left(r^{2}=0.94\right)$ and ranged between 1 and 4 pmol Si per cell (Fig. 7A). The cellular Si quotas in the Fe-limited (Cont/ $+\mathrm{Zn}$ ) samples were 3.3-fold higher than in the Fereplete samples $(P<0.005)$. At site $4, \mathrm{Si}$ quotas estimated from both measurements were less well correlated $\left(r^{2}=0.61\right)$. A significant decrease of the cellular $\mathrm{Si}$ quota was observed in the $+\mathrm{Fe}$ treatment, by a factor of 2 from the BSi per cell estimate or by a factor of 3 from the silicic acid drawdown estimate (Fig. 7B). Both $\mathrm{Zn}$ treatments $(+\mathrm{Zn}$ and $+\mathrm{FeZn})$ exhibited similar $\mathrm{Si}$ quotas which were slightly lower than the control. However, this decrease was not significant except for the Si quota estimated from BSi per cell in the $+\mathrm{Zn}$ treatment.

\subsection{The sub-Antarctic Zone-a low silicate HNLC area}

\subsubsection{Phytoplankton biomass}

As only duplicate treatments were available for this experiment, error bars represent the range of measurements but not the standard deviation. Each histogram bar represents the average value calculated for each set of duplicates.

The Chl $a$ data indicated a general two-fold increase of biomass by day 3 in all treatments except the control (Fig. 8A). By day 7 however, $\mathrm{Chl} a$ concentrations were well differentiated. The lowest concentration $\left(0.45 \mu \mathrm{g} \mathrm{L}^{-1}\right)$ was observed in the control and the highest in the combined FeSi amendments $\left(2.47 \mu \mathrm{g} \mathrm{L}^{-1}\right)$. Fe additions alone increased $\mathrm{Chl} a$ by a factor of 3 compared to the control. The $+\mathrm{Si},+\mathrm{ZnSi}$ and $+\mathrm{FeZnSi}$ amendments reached intermediate values of 
SAZ site
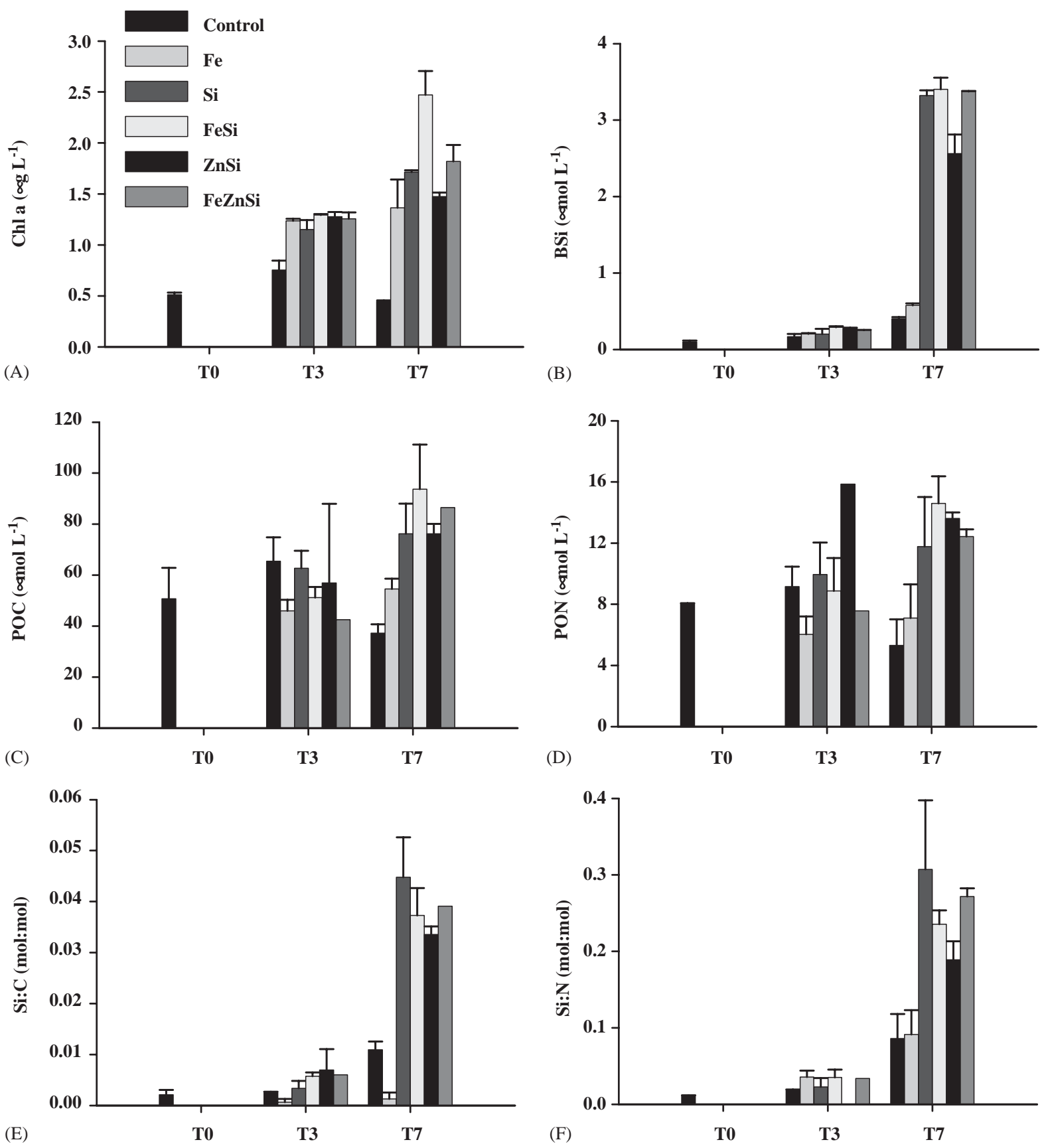

Fig. 8. Biomass parameters at the Sub-Antarctic site. (A) Chl $a$ in $\mu \mathrm{g} \mathrm{L}^{-1}$, (B) BSi in $\mu \mathrm{mol} \mathrm{L}^{-1}$, (C) $\mathrm{POC}$ in $\mu \mathrm{mol} \mathrm{L}{ }^{-1}$, (D) PON in $\mu \mathrm{mol} \mathrm{L}{ }^{-1}$, (E) BSi:POC molar ratios in mol:mol, and (F) BSi:PON molar ratios in mol:mol. Histogram bars are the averages and error bars represent the range of variation of duplicate bottles. BSi:POC and BSi:PON ratios were derived from the ratio of average values of $\mathrm{BSi}, \mathrm{POC}$ and PON for each duplicate treatment. 
$1.47-1.82 \mu \mathrm{g} \mathrm{L}^{-1}$. BSi was initially very low $\left(<0.10 \mu \mathrm{mol} \mathrm{L}^{-1}\right)$ and increased only slightly in all treatments by day 3 (Fig. 8B). By the final day of the experiment, BSi concentrations increased sharply in the treatments with added $\mathrm{Si}$ (6-8 times relative to the control) and reached a maximum value of $3.40 \mu \mathrm{mol} \mathrm{L}^{-1}$ in the $+\mathrm{FeSi}$ treatments. There were no major differences between the $+\mathrm{Si}$, $+\mathrm{FeSi},+\mathrm{ZnSi}$ and $+\mathrm{FeZnSi}$ amendments. $\mathrm{Fe}$ additions alone had only a small impact on BSi accumulation compared to the control.

POC did not increase between days 0 and 3, with slightly lower values in all treatments compared to the control (Fig. 8C). On the last day of the experiment, POC concentration was lowest in the control treatment $\left(37.2 \mu \mathrm{mol} \mathrm{L}^{-1}\right)$ and highest in the $\mathrm{FeSi}$ amendment $\left(93.7 \mu \mathrm{mol} \mathrm{L}{ }^{-1}\right)$. POC concentrations more than doubled in all the + Si treatments compared to the control and was intermediate in the Fe addition. PON values followed the same general pattern as POC (Fig. 8D). By day 7, PON concentrations in the combined trace metal and $\mathrm{Si}$ additions were 2-3 times higher than the control, while $\mathrm{Fe}$ alone only increased PON concentrations by $25 \%$.

BSi:POC and BSi:PON molar ratios also followed the same trend, and absolute values were much lower than in the Bering Sea experiment (Fig. 8E and F). BSi:POC ratios remained extremely low $(<0.01)$ compared to the average ratio of 0.13 for growing diatoms (Brzezinski, 1985) up to day 3. On the last day of the experiment, the ratio was still low in the control and $\mathrm{Fe}$ treatments $(0.01)$ but increased significantly in all Si amendments (0.03-0.05). BSi:PON ratios were similarly initially very low $(<0.02)$ and increased to values between 0.16 and 0.40 in all $\mathrm{Si}$ amendments.

\subsection{Diatom abundance and community structure}

Total diatom abundance and community structure were analyzed initially and for the final day of the experiment. At T0, diatom abundance was very low (data not shown) and represented $40 \%$ of the total microphytoplankton counts while dinoflagellates contributed $60 \%$. Small nanoflagellate cells $(<5 \mu \mathrm{m})$ were numerically dominant. By the

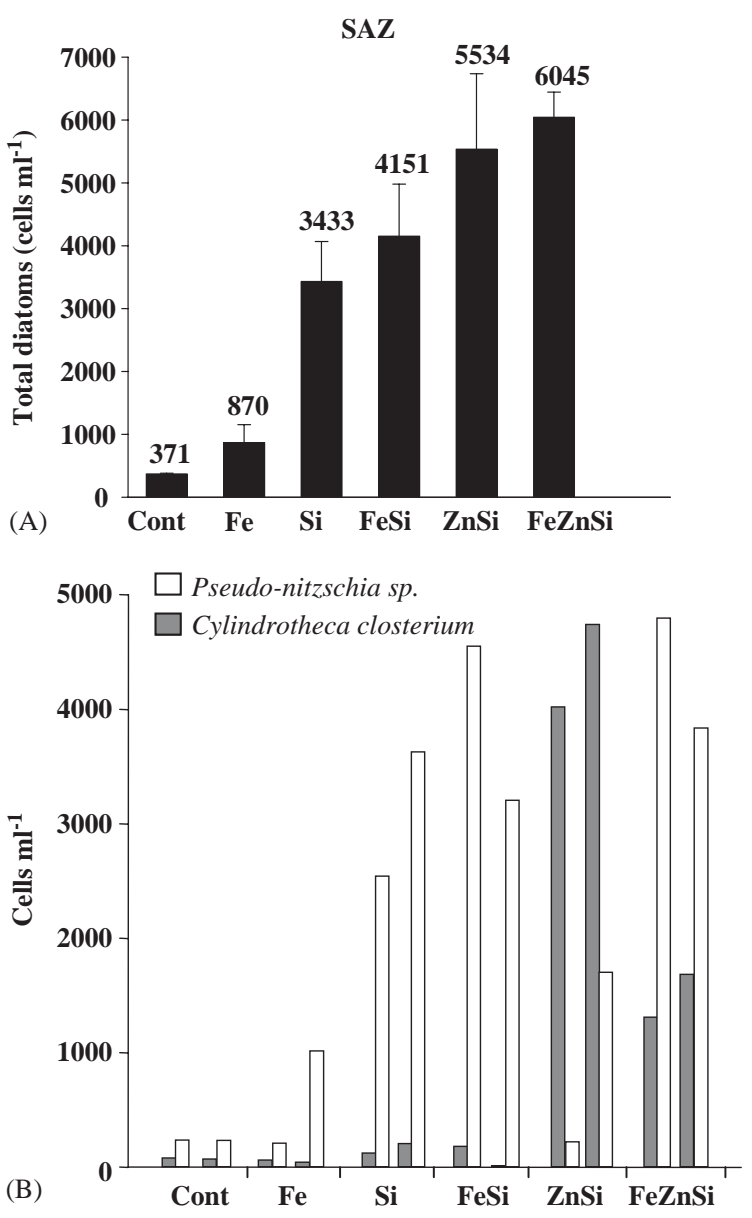

Fig. 9. (A) Total diatom abundance on the final day (day 7) in the Sub-Antarctic experiment. Average counts for duplicate bottles. Each histogram bar represents the average value calculated for each set of duplicates and error bars represent the range of variation of duplicate bottles. (B) Total cell abundance (cells $\mathrm{mL}^{-1}$ ) on the final day of the two dominant species Cylindrotheca closterium and Pseudo-nitzschia sp. in duplicate bottles.

final day of the experiment, diatom abundance remained low in the control treatments and showed a slight increase in the Fe treatment (Fig. 9A). In contrast, diatoms increased by more than an order of magnitude in all $\mathrm{Si}$ treatments compared to the control, to between 3400 and 6000 cells $\mathrm{mL}^{-1}$, with the highest concentrations observed in the $+\mathrm{FeZnSi}$ bottles.

At the end of this experiment, the diatom community was almost entirely co-dominated by 
two pennate species (Fig. 9B). The abundance of all other species remained well below 200 cells $\mathrm{mL}^{-1}$ ( 20 cells $\mathrm{mL}^{-1}$ on average) and is therefore not presented. Centric diatoms were in low abundance in all treatments and represented at most $7 \%$ in the control and $12.5 \%$ in the $\mathrm{Fe}$ treatments (data not shown).

The two dominant pennate species were very similar to the ones observed in the Bering Sea. A large chain forming Pseudo-nitzschia sp. ( $>50 \mu \mathrm{m})$ was observed together with the much smaller and more slender Cylindrotheca closterium $(20 \mu \mathrm{m})$. The microplanktonic Pseudo-nitszchia sp. was dominant in the $+\mathrm{Fe}$, $+\mathrm{Si}$, and $+\mathrm{FeSi}$ amendments, representing $90-97 \%$ of the pennate community (Fig. 9B). The contribution of the smaller Cylindrotheca closterium increased in the control, where it constituted $23 \%$ of the total pennate abundance and in the FeZnSi treatment where it constituted $26 \%$, but with cell numbers an order of magnitude higher. Interestingly, the abundance of Cylindrotheca closterium increased significantly in both $\mathrm{Zn}$ additions $(+\mathrm{ZnSi}$ and $+\mathrm{FeZnSi})$. There was a particularly drastic shift in dominance from Pseudo-nitzschia to Cylindrotheca in both duplicates for the $\mathrm{ZnSi}$ treatments, where the latter species represented $83 \%$ of all pennates. This important increase of a smaller diatom in all $\mathrm{Zn}$ amended treatments was also reflected in the sizefractionated $\mathrm{Chl} a$ data, which showed a two-fold decrease of the $>20 \mu \mathrm{m}$ size-class Chl $a$ values between the $\mathrm{Si}$ and $\mathrm{ZnSi}$ amendments and a similar decrease between the FeSi and FeZnSi amendments (Table 2).

\subsection{Nutrient drawdown}

$\mathrm{NO}_{3}^{-}$concentrations were initially $6.6 \mu \mathrm{M}$ but decreased quickly to $1.2-1.5 \mu \mathrm{M}$ in all $+\mathrm{Si}$ amendments (Fig. 10A). Only 17\% of the initial nitrate stock was used in the control, while in the + Fe treatment, a drawdown of $55 \%$ of the initial stock occurred. Initial $\mathrm{Si}(\mathrm{OH})_{4}$ concentrations at the time of water collection were extremely low $(0.45 \mu \mathrm{M})$. In the four $+\mathrm{Si}$ amendments, $\mathrm{Si}(\mathrm{OH})_{4}$ concentrations were depleted to below the initial concentration by the end of the experiment, with an average $0.20 \mu \mathrm{M}$ remaining (Fig. 10B). The dissolved Si:N drawdown ratio was slightly negative for the control (Fig. 10C) due to a small increase in $\mathrm{Si}(\mathrm{OH})_{4}$ concentration over time, either due to dissolution processes or to the precision of the measurement. The Si:N drawdown ratio was also very low in the $+\mathrm{Fe}$ treatment on day $3(0.04)$ and day 7 (0.08). In all $\mathrm{Si}$ amendments, the $\mathrm{Si}: \mathrm{N}$ drawdown ratio was between 0.9 and 1.1 on day 3 , but decreased by day 7 to relatively uniform values of $0.7-0.8$.

\subsection{Si cellular quotas}

As in the Bering Sea experiments, we compared changes in "average" Si cellular quotas in the SAZ for the samples with very similar species composition. The control and + FeZnSi treatment exhibited the same relative species abundance, and the same is true for the $+\mathrm{Si}$, the $+\mathrm{FeSi}$ treatments and one of the $+\mathrm{Fe}$ replicates. However, species composition in the $+\mathrm{ZnSi}$ treatment differed too much to be included in this comparison.

The cellular Si content was derived by dividing BSi concentrations by the total diatom abundance (Fig. 11). The average Si quota per diatom was slightly over $1 \mathrm{pmol}$ in the control treatment (Fig. 11A) and decreased by almost half in the + FeZnSi treatments (average of $0.56 \mathrm{pmol} \mathrm{Si} \mathrm{per}$ cell). The diatoms present in the control thus appear more silicified than in the $+\mathrm{FeZnSi}$ treatment, despite the fact that the overall community BSi:POC ratio had increased considerably

Table 2

Effects of $\mathrm{Zn}$ on the $>20 \mu \mathrm{m} \mathrm{Chl} a$ size fraction in different treatments (expressed as a percentage of the total Chl $a$ ) on the final day of the Sub-antarctic experiment (day 7)

\begin{tabular}{llll}
\hline Treatment & $\%$ of Chl $a>20 \mu \mathrm{m}(\%)$ & Treatment & $\%$ of Chl $a>20 \mu \mathrm{m}(\%)$ \\
\hline $\mathrm{Si}$ & 84 & $\mathrm{FeSi}$ & 75 \\
$\mathrm{Si}+\mathrm{Zn}$ & 43 & $\mathrm{FeSi}+\mathrm{Zn}$ & 40 \\
\hline
\end{tabular}



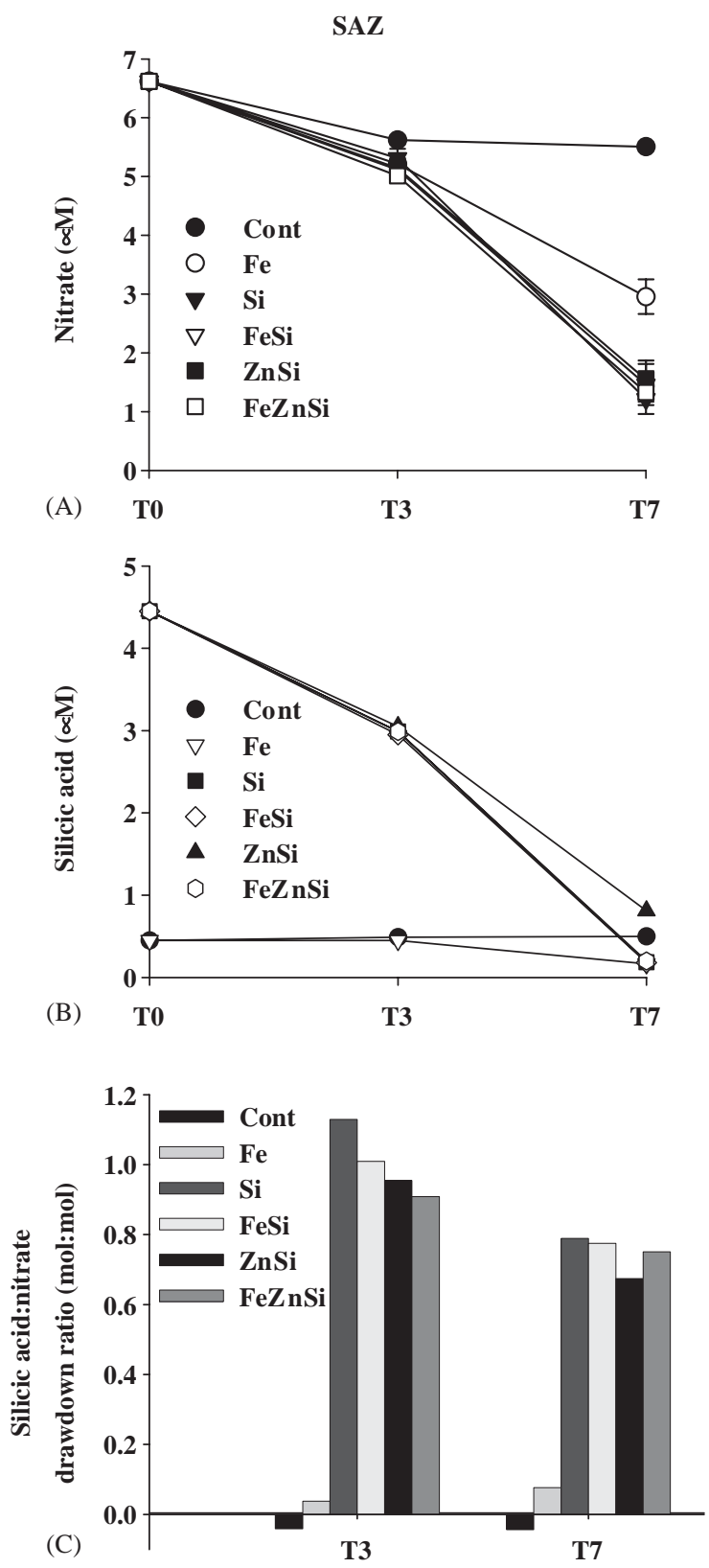

(A)
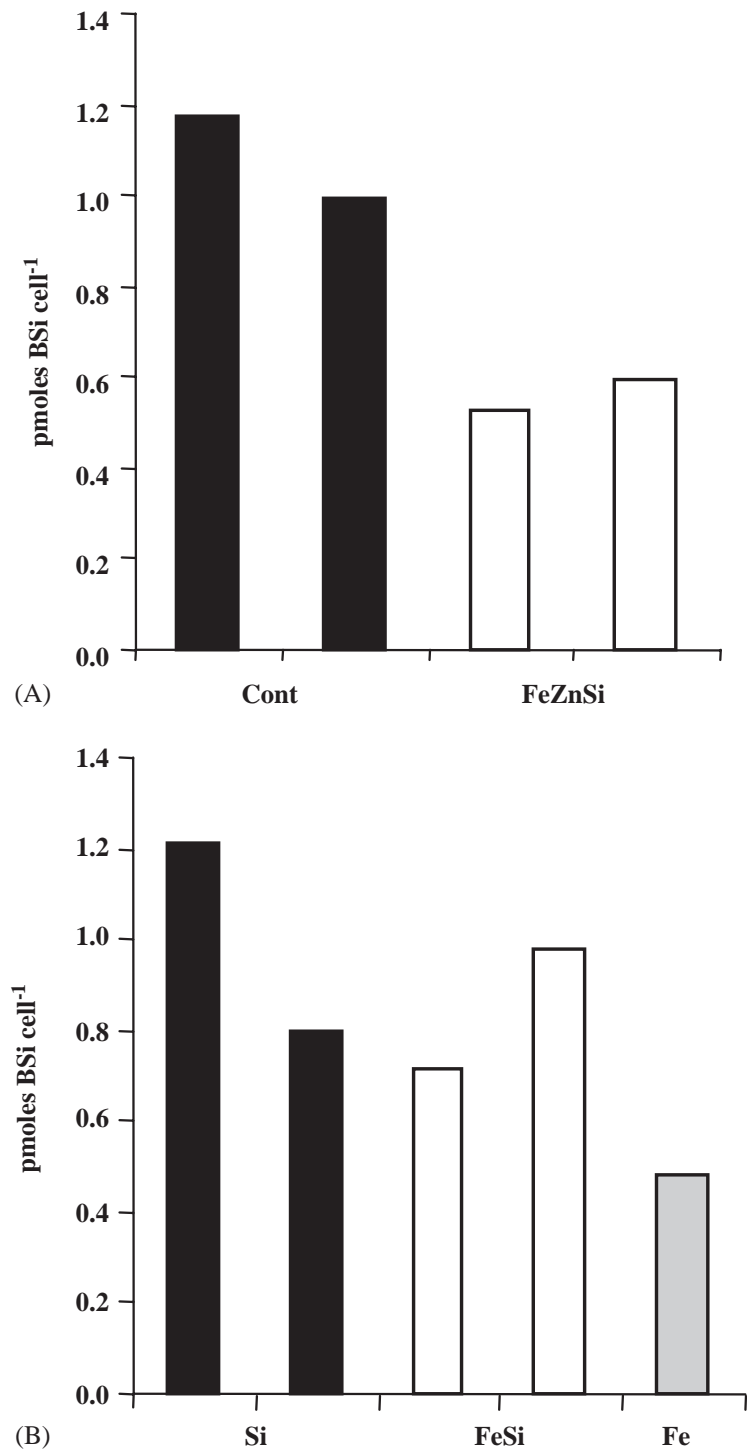

Fig. 11. Cellular Si quotas (in pmol $\mathrm{Si}$ cell $^{-1}$ ) of duplicate treatments in the SAZ derived from biogenic silica only, as one set of the silicic acid duplicates was contaminated on the last day. Si quotas are compared in panel A and B only in between samples with similar relative species composition. In panel B, one replicate of the $+\mathrm{Fe}$ treatment showed a similar species composition compared to the $+\mathrm{Si}$ and $+\mathrm{FeSi}$ and was included in the comparison.

Fig. 10. (A and $\mathrm{B}) \mathrm{NO}_{3^{-}}$and $\mathrm{Si}(\mathrm{OH})_{4}$ utilization $(\mu \mathrm{M})$ in the Sub-Antarctic during the course of the experiment. Nitrate values are the average of both duplicate bottles for each treatment and the error bars represent the range of variation of the data. Only single points are given for silicic acid as contamination occurred in all duplicate treatments upon analysis. (C) Calculated Si:N drawdown ratios. 
less in the control by day 7 (Fig. 8E). This can be explained by the presence of a greater proportion of non-siliceous phytoplankton in the control, resulting in a lower community BSi:POC ratio relative to the metal addition treatment. The average $\mathrm{Si}$ quota was also close to $1 \mathrm{pmol}$ in the + Si treatments (Fig. 11B). The average Si quota was slightly lower in the $+\mathrm{FeSi}$ treatments compared to the $+\mathrm{Si}$, with a decrease from 1.0 to $0.85 \mathrm{pmol}$. The Si content decreased much more in the $+\mathrm{Fe}$ treatment compared to the $+\mathrm{Si}$ (by $50 \%$ ), but only one replicate was available for comparison.

\section{Discussion}

\subsection{The Bering Sea-HNLC area}

\subsubsection{Nutrient limitation-The role of $\mathrm{Fe}$ and $\mathrm{Zn}$}

Previous work on Fe limitation in the SubArctic Pacific has mainly been conducted in the North-Eastern Gulf of Alaska (Martin and Fitzwater, 1988; La Roche et al., 1996; Harrison et al., 1999; Fujishima et al., 2001; Nishioka et al., 2001). These studies documented potentially limiting surface Fe concentrations in the Sub-Arctic Pacific as low as $0.01 \mathrm{nM}$. In the Alaskan Gyre, the supply of $\mathrm{Fe}$ is thought to be almost entirely (98\%) supported by aeolian dust inputs from various sources including Alaska and the Asian deserts (Duce and Tindale, 1991; Boyd et al., 1998), but advected coastal eddies (Tabata, 1982; Crawford and Whitney, 1999) may also contribute to the Fe supply offshore. Fe-induced diatom blooms observed during two in situ fertilization experiments conducted in the Western (SEEDS, 2001) and in the Eastern Sub-Arctic Pacific (SERIES, 2002) confirmed that these HNLC waters were indeed Fe-limited (Tsuda et al., 2003; Crawford et al., 2003; Boyd et al., 2004).

In the HNLC waters of the Bering Sea however, only a few previous measurements of $\mathrm{Fe}$ and photosynthetic efficiency $\left(F_{v} / F_{m}\right)$ (Suzuki et al., 2002; Fujishima et al., 2001) as well as a modeling study (Moore et al., 2002) have suggested potentially Fe-limiting conditions. To date, no bioassays have been conducted in the region. The present study clearly substantiates the role of $\mathrm{Fe}$ in limiting diatom growth rate in this region during summer. The addition of a relatively moderate amount of $\mathrm{Fe}(+0.25 \mathrm{nM})$ induced a large increase in diatom cell abundance and an increase of all the biomass indicators ( $\mathrm{Chl} a, \mathrm{BSi}, \mathrm{POC}$ and $\mathrm{PON}$ ) at both study sites.

Field data is now accumulating to show that $\mathrm{Fe}$ can play a primary role in controlling major nutrient stoichiometry. The general trend observed in several regimes is an increase in Si: $\mathrm{N}$ drawdown ratios under Fe deficiency (Hutchins and Bruland, 1998; Takeda, 1998; Franck et al., 2000, 2003; Firme et al., 2003). We found very similar results in this experiment, with significant decreases of the community $\mathrm{Si}: \mathrm{NO}_{3}$ drawdown ratios by a factor 1.7 at site 1 and 4.6 at site 4 in all $\mathrm{Fe}$ amendments, which resulted in both cases from an increased drawdown of $\mathrm{NO}_{3}$ relative to $\mathrm{Si}$ utilization. This alteration of dissolved Si:N drawdown stoichiometry through $\mathrm{Fe}$ addition was followed by a similar decrease in the particulate BSi:PON ratios at both sites, however, this decrease was small and not significant compared to the Fe-deplete samples. This discrepancy between alterations of the Si:N drawdown ratios and BSi:PON ratios may result from a faster recycling of PON into ammonium or DON compared to BSi dissolution rates, or possibly from luxury intracellular $\mathrm{NO}_{3}$ storage.

However, PON is a non-specific indicator of biomass, and includes other algae, heterotrophic bacteria and zooplankton whereas BSi is characteristic of diatoms only. In order to investigate the impact of trace metals on silicification, we therefore considered the Si quota per diatom cell rather than the Si quota normalized to PON. In Fe-replete samples, cellular $\mathrm{Si}$ quotas decreased significantly (Fig. 7), confirming the role of Fe on Si quotas as suggested by Hutchins and Bruland (1998), Takeda (1998), De La Rocha et al. (2000) and Leynaert et al. (2004).

On the other hand, $\mathrm{Zn}$ additions had no significant impact on diatom growth or cellular $\mathrm{Si}$ quotas in these experiments. Several studies on diatom cultures have documented limited diatom growth through reduced $\mathrm{Si}$ uptake rates at free $\mathrm{Zn}^{2+}$ concentrations $<10 \mathrm{pM}$ (Ellwood and Hun- 
ter, 2000; Anderson et al., 1978). Thus, the ambient $\mathrm{Zn}$ levels $(60 \mathrm{pM})$ may already have been sufficient to support diatom growth and explain the lack of response to the $\mathrm{Zn}$ additions.

\subsection{Sub-Antarctic Zone-HNLSiLC}

\subsubsection{Nutrient limitation-The role of Si and trace metals}

The enrichment experiment conducted in the SAZ indicated that diatoms were not primarily limited by $\mathrm{Fe}$, as evidenced by the small increase in $\mathrm{BSi}$ and cell abundance in the $\mathrm{Fe}$ addition alone. The significant increase in Chl $a$ observed in the $+\mathrm{Fe}$ treatment could result from the stimulation of growth of a non-siliceous fraction of the phytoplankton assemblage that was affected by Fe limitation, or by an increase of Chl $a$ per cell, which is commonly seen in Fe addition experiments (Falkowski and LaRoche, 1991). In a companion study conducted during the same cruise (Ellwood, 2004), Fe seemed to be the primary limiting factor affecting bulk Chl $a$ variations and nutrient drawdown. Both experiments were conducted in the same region, but water was collected a day apart, which might be sufficient to introduce variability in the initial phytoplankton community.

On the other hand this experiment clearly demonstrated the limiting role of $\mathrm{Si}$ on diatom growth in this HNLSiLC regime in summer. Silicic acid was depleted to sub-micromolar levels at the beginning of the experiment, and did not allow any substantial increase of diatom cell abundance in the control bottles (Fig. 8). The increase of diatom abundance in the Fe addition was small and nonsignificant, whereas the addition of $4 \mu \mathrm{M}$ of $\mathrm{Si}$ alone or in combination with trace metals allowed pennate diatoms to increase by a factor of $10 \times$ to $20 \times$. Significant differences in the $\mathrm{Si}: \mathrm{NO}_{3}$ drawdown ratios as well as the particulate BSi:PON and BSi:POC ratio were only observed between the control $/+\mathrm{Fe}$ treatments and all other $\mathrm{Si}$ amendments, with the pronounced growth of diatoms in the latter treatments resulting in much higher $\mathrm{Si}(\mathrm{OH})_{4}: \mathrm{NO}_{3}$ drawdown ratios and similarly higher BSi:POC and BSi:PON ratios. Thus, the supply of $\mathrm{Si}$ to the natural phytoplankton community could elicit a large response of the siliceous component and appears to be the proximate limiting nutrient controlling diatom growth rates, followed by $\mathrm{Fe}$ to a lesser extent. Several studies furthermore substantiated Si-limitation in the same region south of New Zealand during the SOFeX experiment (Coale et al., 2004; Boyd, 2004).

The extent to which diatoms were truly colimited by both $\mathrm{Si}$ and $\mathrm{Fe}$ is not clear from our data, though limitation processes by both elements are thought to be widespread in the Sub-Antarctic Zone. It has been suggested that $\mathrm{Fe}$ is the proximate limiting nutrient for community production and nitrate drawdown, while Si can exert a secondary control on diatom community structure and Si production (Hutchins et al., 2001; Blain et al., 2002; Sedwick et al., 2002). In our study, parameters like $\mathrm{Chl} a$, POC and diatom abundance seemed to increase to a larger extent after addition of both $\mathrm{Fe}$ and $\mathrm{Si}$ rather than after addition of either element alone (Figs. 8 and 9), suggesting that both $\mathrm{Fe}$ and Si play a major role in controlling diatom growth in the Sub-Antarctic Zone.

A similar study conducted in the Australian SAZ by Hutchins et al. (2001) demonstrated increased growth of very lightly silicified diatoms with $\mathrm{Fe}$ addition alone, despite very low silicic acid values. In our experiment, diatoms clearly did not grow on $\mathrm{Fe}$ additions alone, even if the Si cellular quota seemed to decrease by half in the $\mathrm{Fe}$ addition compared to the $+\mathrm{Si}$ treatment (Fig. 11B). Thus, it appears that seasonal and/or spatial differences in the proximate limiting factor ( $\mathrm{Fe}$ or $\mathrm{Si}$ ) may occur in the low-Si waters of the SAZ. This succession may in turn depend on the initial diatom community present and on the varying ability of certain species to grow very lightly silicified cell walls.

\subsection{Fe and $\mathrm{Zn}$ role on diatom community structure}

The addition of $\mathrm{Fe}$ alone seemed to have a slight impact on community structure (Fig. 9) by increasing the relative abundance of the larger diatom Pseudo-nitzschia sp. compared to the smaller species Cylindotheca closterium. However, 
the combined addition of $\mathrm{Fe}$ and $\mathrm{Si}$ did not show any differences in diatom community structure compared to the + Si treatment, which were both almost entirely dominated by the colonial pennate Pseudo-nitzschia sp. On the other hand, this experiment revealed a strong and unprecedented change in the diatom community structure following $\mathrm{Zn}$ addition. The diatom enumeration data presented in Fig. 9B evidenced a drastic change from Pseudo-nitzschia sp. towards the dominance of Cylindrotheca closterium, a smaller and solitary cell, which was visible as a hair-like structure under light microscopy $(\times 400)$.

To date, the effect of $\mathrm{Zn}$ on autotrophic communities has been poorly documented in the natural environment. Several enrichment experiments similar to ours, performed in different areas of the Southern Ocean during SOIREE (Frew et al., 2001; Gall et al., 2001) and AESOPS (Cochlan et al., 2002; Coale et al., 2003) showed no impact of $\mathrm{Zn}$ on bulk biomass, silicic acid and $\mathrm{N}$ uptake or community structure. The first substantial evidence of a stimulation of phytoplankton growth attributed to $\mathrm{Zn}$ was documented by Crawford et al. (2003) in the Sub-Arctic Pacific at station PAPA. Their study demonstrated small but significant increases on bulk parameters like Chl $a, P_{\mathrm{B}}^{\max }$ values and nutrient drawdown, together with a change in the phytoplankton community structure, with a slight increase $(10 \%)$ of small pennate diatoms in a combined $+\mathrm{FeZn}$ treatment compared to their + Fe treatment.

In the SAZ, Zn concentrations were the lowest documented so far for any open ocean region $(6 \mathrm{pM})$ and close to the values shown to be limiting for diatom growth in laboratory experiments (Brand et al., 1983; Sunda and Huntsman, 1995). The involvement of $\mathrm{Zn}$ in $\mathrm{Si}$ transporters has not been documented, but effects of $\mathrm{Zn}$ on Si uptake kinetic parameters have been shown in culture experiments (De La Rocha et al., 2000) and in HNLC regions (Franck et al., 2003). This suggests that, through subtle changes of $\mathrm{Si} K_{S}$ constants and $V_{\max }$ values, a regime shift from $\mathrm{Zn}$-limited to $\mathrm{Zn}$-replete conditions could modify diatom community structure, by giving a competitive edge to diatoms with lowered half-saturation constants for Si.

\section{Conclusion}

The two high-latitude HNLC systems were controlled by contrasting limiting nutrients during summer. There was clear evidence of Felimitation in the high-Si HNLC Bering Sea Gyre, where macronutrients in the Sub-Arctic Pacific were sufficient to allow a strong increase of diatom abundance with the addition of $\mathrm{Fe}$ alone. The alleviation of Fe-limitation also led to a decrease in the average cellular $\mathrm{Si}$ content by a factor of 2 to 3, supporting previous work (Hutchins and Bruland, 1998; Takeda, 1998; De La Rocha et al., 2000; Franck et al., 2000, 2003; Firme et al., 2003). However, Fe additions did not modify diatom community structure.

In the $\mathrm{SAZ}, \mathrm{Si}$ appeared to be the proximate limiting factor for the diatom community during summer, with secondary Fe-limitation processes. The Si-limitation occurring in the northern part of the SAZ may thus potentially counteract the impact of an increased Fe-input to surface waters, as suggested by Coale et al. (2004) and Boyd (2004) during the SOFeX experiment. This indicates that in order to increase the efficiency of the biological pump in the Southern Ocean, Fe- but also Si-limitation needs to be alleviated in parts of the SAZ.

Our data from the SAZ furthermore constitutes the first conclusive field evidence of a role for $\mathrm{Zn}$ in controlling diatom community structure, shifting the composition away from a larger colonial pennate towards a smaller unicellular species. However, the reasons for such changes could not be inferred from the present study, and further work at the species-specific level is also required to identify the interactions between the $\mathrm{Si}$ and $\mathrm{Zn}$ biogeochemical cycles and diatom community composition. By modifying either cell size, silicification rates or species composition, the availability of trace metals such as $\mathrm{Fe}$ and $\mathrm{Zn}$ may significantly alter Si:N:P:C uptake and biomass ratios, which in turn has strong large implications for phytoplankton dynamics and the efficiency of the biological pump. 


\section{Acknowledgements}

This work was supported by NSF grants 0094535,0328483 and 0327724 to D. Hutchins, grant OCE-0137085 to K. Bruland, as well as NIWA support to P. Boyd. We thank Russell Frew and Geoffrey Smith for setting up the clean pumping systems on board. We also wish to express our gratitude to the captain and crews of the R/V Tangaroa and R/V Kilo Moana for their valuable assistance at sea.

\section{References}

Aksnes, D.L., Egge, J.K., Rosland, R., Heimdal, B.R., 1994. Representation of Emiliania huxleyi in phytoplankton simulation-models - a 1st approach. Sarsia 79, 291-300.

Anderson, M.A., Morel, F.M.M., Guillard, R.R.L., 1978. Growth limitation of a coastal diatom by low zinc ion activity. Nature 276, 70-71.

Bakker, D.C.E., Watson, A.J., Law, C.S., 2001. Southern Ocean iron enrichment promotes inorganic carbon drawdown. Deep-Sea Research II 48, 2483-2508.

Blain, S., Sedwick, P.N., Griffiths, F.B., Queguiner, B., Bucciarelli, E., Fiala, M., Pondaven, P., Treguer, P., 2002. Quantification of algal iron requirements in the Subantarctic Southern Ocean (Indian sector). Deep-Sea Research II 49, 3255-3273.

Boyd, P.W., 2004. Ironing out algal issues in the Southern Ocean. Science 304, 396-397.

Boyd, P.W., Wong, C.S., Merrill, J., Whitney, F., Snow, J., Harrison, P.J., Gower, J., 1998. Atmospheric iron supply and enhanced vertical carbon flux in the NE subarctic Pacific: is there a connection? Global Biogeochemistry Cycles 12 (3), 429-441.

Boyd, P.W., et al., 2000. A mesoscale phytoplankton bloom in the polar Southern Ocean stimulated by iron fertilization. Nature 407, 695-702.

Boyd, P.W., et al., 2004. The decline and fate of an ironinduced subarctic phytoplankton bloom. Nature 428, $549-553$.

Brand, L.E., Sunda, W.G., Guillard, R.R.L., 1983. Limitation of marine phytoplankton reproductive rates by zinc, manganese and iron. Limnology and Oceanography 28, 1182-1198.

Bruland, K.W., 1980. Oceanographic distributions of Cd, Zn, $\mathrm{Cu}$ and $\mathrm{Ni}$ in the North Pacific. Earth and Planetary Science Letters 47, 176-198.

Bruland, K.W., 1989. Complexation of zinc by natural organic ligands in the Central North Pacific. Limnology and Oceanography 34, 269-285.

Bruland, K.W., Franks, R.P., 1983. Mn, Ni, Cu, Zn, and Cd in the Western North Atlantic. In: Wong, C.S., Boyle, E., Bruland, K.W., Burton, J.D., Goldberg, E.D. (Eds.), Trace
Metals in Sea-water. NATO Conference Series IV Marine Sciences. Plenum, New York, pp. 395-414.

Bruland, K.W., Franks, R.P., Knauer, G.A., Martin, J.H., 1979. Sampling and analytical methods for the determination of copper, cadmium, zinc, and nickel at the nanogram per liter level in seawater. Analytica Chimica Acta 105, 233-245.

Bruland, K.W., Rue, E.L., Geoffrey, J.S., DiTullio, G.R., 2005. Iron, macronutrients and diatom blooms in the Peru upwelling regime: brown and blue waters of Peru. Marine Chemistry 93 (2-4), 81-103.

Brzezinski, M.A., 1985. The Si:C:N ratios of marine diatoms: interspecific variability and the effect of some environmental variables. Journal of Phycology 21, 345-357.

Brzezinski, M.A., Dickson, M.L., Nelson, D.M., Sambrotto, R., 2003. Ratios of $\mathrm{Si}, \mathrm{C}$ and $\mathrm{N}$ uptake by microplankton in the Southern Ocean. Deep-Sea Research II 50, 19-633.

Buesseler, K.O., 1998. The decoupling of production and particulate export in the surface Ocean. Global Biogeochemical Cycles 12 (2), 297-310.

Coale, K.H., 1991. Effects of iron, manganese, copper, and zinc enrichments on productivity and biomass in the subarctic Pacific. Limnology and Oceanography 36, 1851-1864.

Coale, K.H., Johnson, K.S., Fitzwater, S.E., et al., 1996. A massive phytoplankton bloom induced by an ecosystemscale iron fertilization experiment in the Equatorial Pacific Ocean. Nature 383, 495-501.

Coale, K.H., Wang, X., Tanner, S.J., Johnson, K.S., 2003. Phytoplankton growth and biological response to iron and zinc addition in the Ross Sea and Antarctic Circumpolar Current along $170 \mathrm{~W}$. Deep-Sea Research II 50, 635-653.

Coale, K.H., et al., 2004. Southern Ocean iron enrichment experiment: carbon cycling in high- and low-Si waters. Science 304, 408-414.

Cochlan, W.P., Bronk, D.A., Coale, K.H., 2002. Trace metals and nitrogenous nutrition of Antarctic phytoplankton: experimental observations in the Ross Sea. Deep-Sea Research II 49, 3365-3390.

Crawford, W.R., Whitney, F., 1999. Mesoscale eddies aswirl with data in Gulf of Alaska Ocean. EOS, Transactions of the American Geophysical Union 80 (33), 365-370.

Crawford, D.W., et al., 2003. Influence of zinc and iron enrichments on phytoplankton growth in the northeastern subarctic Pacific. Limnology and Oceanography 48, $1583-1600$.

De La Rocha, C.L., Hutchins, D.A., Brzezinski, M.A., Zhang, Y., 2000. Effects of iron and zinc deficiency on elemental composition and silica production by diatoms. Marine Ecological Progress Series 195, 71-79.

Duce, R.A., Tindale, N.W., 1991. Atmospheric transport of iron and its deposition in the ocean. Limnology and Oceanography 36, 1715-1726.

Dugdale, R.C., Wilkerson, F.P., Minas, H.J., 1995. The role of a silicate pump in driving new production. Deep-Sea Research I 42, 697-719. 
Ellwood, M.J., 2004. Zinc and cadmium speciation in subantarctic waters east of New Zealand. Marine Chemistry $87,37-58$.

Ellwood, M.J., Hunter, K.A., 2000. The incorporation of zinc and iron into the frustule of the marine diatom Thalassiosira pseudonana. Limnology and Oceanography 45, 1517-1524.

Ellwood, M.J., van den Berg, C.M.G., 2000. Zinc speciation in the Northeastern Atlantic Ocean. Marine Chemistry 68, 295-306.

Firme, G.F., Rue, E.L., Weeks, D.A., Bruland, K.W., Hutchins, D.A., 2003. Spatial and temporal variability in phytoplankton iron limitation along the California coast and consequences for $\mathrm{Si}, \mathrm{N}$, and $\mathrm{C}$ biogeochemistry. Global Biogeochemical Cycles 17, 16.1-16.3.

Falkowski, P.G., LaRoche, J., 1991. Molecular biology in the study of ocean processes. International Review in Cytology 128, 261-303.

Franck, V.M., Brzezinski, M.A., Coale, K.H., Nelson, D.M., 2000. Iron and silicic acid concentrations regulate Si uptake north and south of the polar frontal zone in the Pacific sector of the Southern Ocean. Deep-Sea Research II 47, 3315-3338.

Franck, V.M., Bruland, K.W., Hutchins, D.A., Brzezinski, M.A., 2003. Iron and zinc effects on silicic acid and nitrate uptake kinetics in three high-nutrient, low-chlorophyll (HNLC) regions. Marine Ecological Progress Series 252, $15-33$.

Frew, R., Bowie, A., Croot, P., Pickmere, S., 2001. Macronutrient and trace-metal geochemistry of an in situ ironinduced Southern Ocean bloom. Deep-Sea Research II 48, 2467-2481.

Fujishima, Y., Ueda, K., Maruo, M., Nakayama, E., Tokutome, C., Hasegawa, H., Matsui, M., Sohrin, Y., 2001. Distribution of trace bioelements in the Subarctic North Pacific Ocean and the Bering Sea (the R/V Hakuho Maru Cruise KH-97-2). Journal of Oceanography 57, 261-273.

Gall, M.P., Strzepek, R., Maldonado, M., Boyd, P.W., 2001. Phytoplankton processes. Part 2: Rates of primary production and factors controlling algal growth during the Southern Ocean Iron RElease Experiment (SOIREE). Deep-Sea Research II 48, 2571-2590.

Geider, R.J., La Roche, J., 1994. The role of iron in phytoplankton photosynthesis, and the potential for ironlimitation of primary productivity in the sea. Photosynthetic Research 39, 275-301.

Gervais, F., Riebesell, U., Gorbunov, M.Y., 2002. Changes in primary productivity and chlorophyll $a$ in response to iron fertilization in the Southern Polar Frontal Zone. Limnology and Oceanography 47, 1324-1335.

Harrison, P.J., Boyd, P.W., Varela, D.E., Takeda, S., Shiomoto, A., Odate, T., 1999. Comparison of factors controlling phytoplankton productivity in the NE and NW subarctic Pacific gyres. Progress in Oceanography 43, 205-234.

Hutchins, D.A., Bruland, K.W., 1998. Iron-limited diatom growth and $\mathrm{Si} N \mathrm{~N}$ uptake ratios in a coastal upwelling regime. Nature 393, 561-564.
Hutchins, D.A., DiTullio, G.R., Zhang, Y., Bruland, K.W., 1998. An iron limitation mosaic in the California upwelling regime. Limnology and Oceanography 43, 1037-1054.

Hutchins, D.A., Sedwick, P.N., DiTullio, G.R., Boyd, P.W., Quéguiner, B., Griffiths, F.B., Crossley, C., 2001. Control of phytoplankton growth by iron and silicic acid availability in the subantarctic Southern Ocean: Experimental results from the SAZ project. Journal of Geophysical Research 106, 31559-31572.

Jickells, T.D., Spokes, L.J., 2001. Atmospheric iron inputs to the oceans. In: Turner, D.R., Hunter, K. (Eds.), The Biogeochemistry of Iron in Seawater. SCOR/IUPAC Series. Wiley, New York, pp. 85-121.

La Roche, J., Boyd, P.W., McKay, R., Geider, R., 1996. Flavodoxin as a marker for iron stress in phytoplankton. Nature 382, 802-805.

Law, C.S., Boyd, P.W., Watson, A.J., 2001. SOIREE-The Southern Ocean iron release experiment. Deep-Sea Research II 48, 2425.

Leblanc, K., Hutchins, D.A., New applications of a biogenic silica deposition fluorophore in the study of oceanic diatoms. In press for Limnol. and Oceanogr. Methods.

Legendre, L., Le Fèvre, L., 1989. Hydrodynamical singularities as controls of recycled versus export production in oceans. In: Berger, W.H., Smetacek, V.S., Wefer, G. (Eds.), Productivity of the Ocean: Present and Past. John Wiley \& Sons Ltd, New York, pp. 49-63.

Leynaert, A., Bucciarelli, E., Claquin, P., Dugdale, R.C., Martin-Jézéquel, V., Pondaven, P., Ragueneau, O., 2004. Effects of iron deficiency on diatom cell size and silicic acid uptake kinetics. Limnology and Oceanography 49 (4), 1134-1143.

Lohan, M.C., Statham, P.J., Crawford, D.W., 2002. Total dissolved zinc in the upper water column of the subarctic North East Pacific. Deep-Sea Research II 49, 5793-5808.

Margalef, R., 1978. Life-forms of phytoplankton as survival alternatives in an unstable environment. Oceanologica Acta 1, 493-509.

Martin, J.H., Fitzwater, S., 1988. Iron deficiency limits phytoplankton growth in the north-east Pacific subarctic. Nature 331, 341-343.

Martin, J.H., Gordon, R.M., Fitzwater, S.E., 1991. The case for iron. Limnology and Oceanography 36, 1793-1802.

Martin, J.H., Coale, K.H., Johnson, K.S., et al., 1994. Testing the iron hypothesis in ecosystems of the equatorial Pacific Ocean. Nature 371, 123-129.

Moore, J.K., Doney, S.C., Glover, D.M., Fung, I.Y., 2002. Iron cycling and nutrient limitation patterns in surface waters of the world ocean. Deep-Sea Research II 49, 463-507.

Morel, F.M.M., Reinfelder, J.R., Roberts, S.B., Chamberlain, C.P., Lee, J.G., Yee, D., 1994. Zinc and carbon co-limitation of marine phytoplankton. Nature 369, 740-742.

Nelson, D.M., Smith, W.O.J., Muench, R.D., Gordon, L.I., Sullivan, C.W., Husby, D.M., 1989. Particulate matter and nutrient distributions in the ice-edge zone of the Weddell 
Sea: relationship to hydrography during late summer. DeepSea Research 36, 191-209.

Nelson, D.M., Tréguer, P., Brzezinski, M.A., Leynaert, A., Quéguiner, B., 1995. Production and dissolution of biogenic silica in the ocean: revised global estimates, comparison with regional data and relationship to biogenic sedimentation. Global Biogeochemical Cycles 9, 359-372.

Nishioka, J.S., Takeda, S., Wong, C.S., Johnson, W.K., 2001. Size-fractionated iron concentrations in the northeast Pacific Ocean: distribution of soluble and small colloidal iron. Marine Chemistry 74 (2-3), 157-179.

Parsons, T.R., Maita, Y., Lalli, C.M., 1984. A manual of chemical and biological methods for seawater analysis. Pergamon Press, Oxford 173pp.

Rue, E.L., Bruland, K.W., 1995. Complexation of iron (III) by natural organic ligands in the Central North Pacific as determined by a new competitive ligand equilibration/ adsorption cathodic stripping voltammetric method. Marine Chemistry 50, 117-138.

Rueter, J.G., Morel, F.M.F., 1981. The interaction between zinc deficiency and copper toxicity as it affects the silicic acid uptake mechanisms in Thalassiosira pseudonana. Limnology and Oceanography 26, 67-73.

Sedwick, P.N., Edwards, P.R., Mackey, D.J., Griffiths, F.B., Parslow, J.S., 1997. Iron and manganese in surface waters of the Australian subantarctic region. Deep-Sea Research I 44, 1239-1253.

Sedwick, P.N., DiTullio, G.R., Mackey, D.J., 2000. Iron and manganese in the Ross Sea, Antarctica: seasonal iron limitation in Antarctic shelf waters. Journal of Geophysical Research 105, 11321-11336.

Sedwick, P.N., Blain, S., Quéguiner, B., Griffiths, F.B., Fiala, M., Bucciarelli, E., Denis, M., 2002. Resource limitation of phytoplankton growth in the Crozet Basin, Subantarctic Southern Ocean. Deep-Sea Research II 49, 3327-3349.

Sharp, J.H., 1991. Total mass and particulate carbon, nitrogen and phosphorus. In: Hurd, D.C., Spencer, D.W. (Eds.), Marine Particles: Analysis and Characterization. Geophys. Monogr. Ser, Vol. 63. AGU, Washington D.C., pp. 87-91.
Shimizu, K., Del Amo, Y., Brzezinski, M.A., Stucky, G.D., Morse, D.E., 2001. A novel fluorescent silica tracer for biological silicification studies. Chemistry and Biology 136, $1-10$.

Strickland, J.D.H., Parsons, T.R., 1972. A practical handbook of seawater analysis. Fishing Research Board of Canadian Bulletin 167, 310 .

Sunda, W.G., Huntsman, S.A., 1995. Iron uptake and growth limitation in oceanic and coastal phytoplankton. Marine Chemistry 50, 189-206.

Suzuki, K., Liu, H., Saino, T., Obata, H., Takano, M., Okamura, K., Sohrin, Y., Fujishima, Y., 2002. East-west gradients in the photosynthetic potential of phytoplankton and iron concentration in the subarctic Pacific Ocean during early summer. Limnology of Oceanography 47, 1581-1594.

Tabata, S., 1982. The anticyclonic, baroclinic eddy off Sitka, Alaska, in the Northeast Pacific Ocean. Journal of Physical Oceanography 12, 1260-1282.

Takeda, S., 1998. Influence of iron availability on nutrient consumption ratio of diatoms in oceanic waters. Nature 393, 774-777.

Timmermans, K.R., Gerringa, L.J.A., de Baar, H.J.W., van der Wagt, B., Veldhuis, M.J.W., de Jong, J.T.M., Croot, P.L., Boye, M., 2001. Growth rates of large and small Southern Ocean diatoms in relation to availability of iron in natural seawater. Limnology and Oceanography 46, 260-266.

Timmermans, K.R., de Baar, H.J.W., van der Wagt, B., 2004. Growth rates, half-saturation constants, and silicate, nitrate and phosphate depletion in relation to iron availability of four large, open-ocean diatoms from the Southern Ocean. Limnology and Oceanography 49 (6), 2141-2151.

Tsuda, A., et al., 2003. A mesoscale iron enrichment in the western subarctic Pacific induces a large centric diatom bloom. Science 300, 958-961.

Vallee, B.L., Auld, D.S., 1990. Zinc coordination, function, and structure of zinc enzymes and other proteins. Biochemistry 29, 5647-5659. 